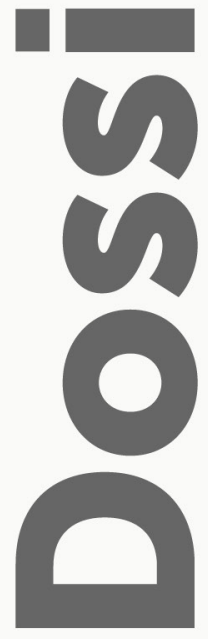

\title{
Luto e Memória da ditadura: O Memorial dos Desaparecidos de Vila Formosa, em São Paulo
}

\author{
Mourning and Memory of the Dictatorship: \\ The Memorial for victims of Enforced Disappearance of Vila \\ Formosa in São Paulo
}

\section{RESUMO}

A transição brasileira para a democracia ocorreu sem rupturas evidentes. Sob a forte presença do legado ditatorial, a formação da memória sobre a repressão da ditadura enfrenta enormes obstáculos para se estabelecer no Brasil. Nesse contexto, este estudo tem por objetivo oferecer um panorama reflexivo sobre o debate teórico a respeito da memória, o trabalho de luto dos familiares de desaparecidos políticos no Brasil, o legado da ditadura e a edificação do Memorial dos Desaparecidos de Vila Formosa, em São Paulo. Propomo-nos aqui a analisar os testemunhos de familiares, sua demanda por "verdade e justiça", e por realizar o luto no Brasil. Ressaltamos que, a despeito dos limites impostos pela transição controlada, o memorial favorece a constituição de uma consciência coletiva acerca da repressão ditatorial, e do status de suas vítimas e sobreviventes no país. Este texto beneficia-se de entrevistas inéditas, documentos pouco explorados e ampla revisão da bibliografia sobre o assunto.

Palavras-chave: Ditadura - Memória Social - Locais de recordação - Presos políticos - Mortos e desaparecidos políticos

\begin{abstract}
Brazilian transition to democracy occurred without notable ruptures. Under the strong legacy of the civil-military dictatorship, the construction of memories on the period's repression faces enormous obstacles to establish itself in Brazil. In this context, this study aims to offer a reflective panorama on the theoretical debate on memory, the mourning process of the families of enforced disappearance victims in Brazil, the legacy of the dictatorship and the construction of the The Memorial for victims of Enforced Disappearance of Vila Formosa in São Paulo. The proposal is to analyze the testimonies of family members, their demand for "truth and justice" and for mourning in Brazil. It is important to stress that in spite of the limits imposed by the negotiated political transition, the The Memorial for victims of Enforced Disappearance of Vila Formosa supports the creation of a collective consciousness about dictatorship repression and the social status of victims and survivors. This text is based on interviews with people directly involved in these events, seldom analysed documents and a broad review of the existing bibliography on the matter.
\end{abstract}

Keywords: Dictatorship - Social Memory - Remembrance places - Political prisoners - enforced disappearances

* Pós-doutora, Doutora e Mestra em História Social pela USP. Secretária-geral do Instituto de Estudos sobre a Violência do Estado (IEVE). Membro do Consejo Latinoamericano de Ciencias Sociales (CLACSO), Argentina. Pesquisadora no projeto "Em defesa da liberdade e da justiça: o papel dos advogados de perseguidos políticos na resistência à ditadura (SP, década 1970)". CV: http://lattes.cnpq.br/9006589887994222 
$\mathrm{Na}$ atualidade, a relação entre história e memória e a reflexão sobre o passado e processos de mudanças políticas e sociais tornaram-se uma preocupação central para as ciências sociais e, mais amplamente, para a sociedade. É possível afirmar que a "cultura da memória" (Huyssen, 2002), assim como as políticas de memória, tornaram-se transnacionais e, até, globais. A recordação passou a ser essencial para a formação identitária, tanto no âmbito individual quanto no coletivo, oferecendo um palco para o conflito e a identificação. Enquanto certos tipos de memória se retraíram - , tais como a memória de aprendizagem, a formativa ou a experencial ${ }^{1}$-, outras formas ganharam importância. Por meio de reivindicações e disputas, estas memórias têm exercido pressões sobre o presente, e se tornam vitais para a formação cultural (Assman, 2011, p. 20).

A emergência da memória de traumas históricos no espaço público durante o século XX, sobretudo após a II Guerra Mundial, impôs uma reconfiguração do status da memória e do recordar. O regime da memória social mudou e o papel da vítima se torna relevante. Desenvolveu-se, então, uma estética do "antimonumento", visando fundir a tradição do monumento com a da comemoração fúnebre (Seligmann-Silva, 2012). Desde a Antiguidade, a tradição de construção de monumentos esteve mais ligada à comemoração de vitórias bélicas e a heróis, do que à ideia de advertir. ${ }^{2}$ No antimonumento, porém, seu sentido heroico é "modificado e deslocado para um local de lembrança", de admoestação da violência e de homenagem aos mortos (Seligmann-Silva, 2012).

Esse esforço de crítica da "heroicização" conduziu à produção de diversos locais de recordação, que afirmavam e legitimavam instituições e valores de grupos vilipendiados no passado. No entanto, em muitos casos, mais do que representar uma ruptura com a tradição cultural ou com a memória formativa, que efetua vínculos com uma nação ou região específica, a "cultura da memória" indica que os excessos de atrocidades cometidos "implodem a capacidade humana de apreender e representar" experiências-limite e a própria história (Assman, 2011, p. 17 e 361).

Se, por um lado, tal ritualística representa uma via à experiência originária da cultura, por outro, conta com o risco da reificação, com a transformação do registro histórico em objeto neutralizado e rentável (Traverso, 2007, p. 68). Em muitos casos, esses instrumentos de (re)memoração seguem transmitindo narrativas oficiais sobre o passado. Como toda narrativa, as versões oficiais são seletivas, embora nem todas devam ser consideradas tão enviesadas ideologicamente, quanto a maior parte das versões oficiais da história (Winter, 2006). Ressaltar certos traços com sinais de heroísmo implica silenciar outros, especialmente os erros e as derrotas. Frente à narrativa oficial, também são construídos relatos e diferentes sentidos do passado, mantidos pela memória e transmissão oral, práticas de resistência ao poder, muitas vezes constituídos nos âmbitos da intimidade ou da clandestinidade (Jelin, 2002, p. 39-42).

Esse debate em torno da atribuição de sentido ao passado está profundamente

1 Tanto a memória formativa quanto a memória de aprendizagem são classificados pela psicologia na categoria de memória semântica (Assman, 2011, p. 17; Ades, 1993).

2 O termo monumento vem do verbo latino "monere" que significa 'fazer recordar' de onde deriva avisar, iluminar, instruir (Le Goff, 1994, p. 535). 
vinculado à análise dos processos e dos atores sociais envolvidos na construção das memórias, especialmente sobre feitos notáveis, cujos efeitos perduram no tempo e no espaço. Ademais, a substância da "arte da memória" é o lugar. Esta é para muitos uma "arte espacial", pois é na "paisagem da memória" que percorre ou age, conforme indica a anedota de Simônides, imortalizada por Platão entre outros, e as origens da mnemotécnica (Weinrich, 2001, p. 30-1).

Para além da presença da palavra escrita na pedra, como nas antigas práticas funerárias e de comemoração, o valor atribuído à visão nesses atos de rememoração é significativo. Com efeito, estes são dirigidos a abrir nossa perspectiva para um passado, para o qual resistimos em dirigir o olhar. Não obstante, a valorização do passado tem ressaltado também a força das palavras e da escuta. É digno de nota, porém, que o frenesi contemporâneo pelas comemorações (Ricoeur, 2007, p. 98) frequentemente realça as limitações dos processos de reavaliação de regimes ditatoriais e da elaboração simbólica de traumas históricos.

Para alguns autores, como a argentina Beatriz Sarlo, o testemunho em juízo tem uma importância política, ética e jurídica incontestável. O problema, porém, residiria no fato de que a historiografia considera estas fontes "mais reveladoras", em comparação com as demais (Sarlo, 2007, p. 11-12). Segundo esta autora, o relato banalizado do cotidiano dos tempos da luta armada apresenta uma visão fechada, heroica e acrítica das práticas militantes e de suas organizações. Ademais, os testemunhos em julgamentos e Comissões da Verdade seriam determinantes apenas quando não há outro tipo de documentação que comprove os crimes cometidos. $^{3}$

O debate atual sobre a relevância da cultura da memória e da legitimidade do relato pessoal, contudo, se estende para além da polarização entre documento escrito e testemunho. Um exemplo emblemático da opção pela exposição pública de testemunhos ocorreu na Comissão de Verdade e Reconciliação sobre os crimes cometidos durante o apartheid na África do Sul. Naquele contexto, a predileção pelo depoimento poderia ser atribuída à ausência de documentos escritos. Entretanto, ao contrário, a opção por dar voz às vítimas tinha por objetivo fortalecer e conceder a máxima visibilidade ao testemunho na esfera pública. Aqueles fatos, pertinentes a toda a sociedade, deveriam inscrever-se na memória pública, por meio da experiência transmitida pelo testemunho, incorporando-os à história do país. ${ }^{4}$

Em consonância com esse debate teórico, neste texto são tratados os trabalhos da memória e do luto relativos aos desaparecimentos forçados, levados a efeito durante a ditadura no Brasil, e da construção de um "local de recordação", no qual foram enterrados desaparecidos políticos na cidade de São Paulo. A análise enfoca os processos históricos que levaram à inauguração deste local. Sua caracterização é aqui considerada, tendo em vista as multiplicidades de vozes e de perspectivas, ancoradas na significação de "lugares traumáticos" (Assman, 2011, p. 351), em face da ameaçadora catástrofe do esquecimento, provocada pela

3 Palestra de Beatriz Sarlo no Instituto Cervantes. São Paulo, Brasil, 31/05/2007. Tal perspectiva recebeu diversas críticas na Argentina. Cf. Oberti (2009), entre outros.

4 Após dois anos de atuação, a CVR ouviu 29 mil pessoas. Desse total, cerca de 7 mil eram agentes da repressão, dos quais 17\% foram anistiados (cerca de 1.100 pessoas), tendo em vista que os demais prestaram falso testemunho ou apresentaram informações incompletas, conforme os documentos existentes indicaram (Teles 2015, p. 13637). 
morte súbita (Weinrich, 2001, p. 30) e do desaparecimento forçado, que transformam o luto e o lembrar em um problema sem fim.

Ressalte-se que, no Brasil, a recuperação factual sobre a repressão política empreendida durante a ditadura, assim como a reflexão sobre os sentidos desse passado permanecem inconclusas. A despeito dos esforços empenhados pela Comissão Nacional da Verdade ${ }^{5}$ e da criação de políticas de memória e reparação, cuja ênfase incidiu sobre a reparação econômica, não há um levantamento exaustivo sobre as pessoas assassinadas ou perseguidas por razões políticas, as circunstâncias de tais crimes e seus responsáveis, entre outros aspectos desse período. ${ }^{6}$

A negação do direito à verdade e à justiça, assim como as limitações nas políticas de reparação referentes ao passado recente têm dificultado ou impedido a articulação e a transmissão das memórias desses anos de violência, fundamentais para a elaboração simbólica, o trabalho de luto e a construção de um referencial crítico sobre esse período. Nesse contexto, insere-se o debate em torno das heranças da repressão ditatorial no Brasil e, particularmente, em São Paulo, conforme será abordado a seguir.

\section{Desaparecimento forçado, luto e os trabalhos da memória no Brasil}

No Brasil, ao contrário de diversos países latino-americanos, nos quais o ocaso da ditadura gerou investigações e o julgamento dos responsáveis pelos crimes das ditaduras, a elaboração traumática e o luto não alcançaram as ruas nem tiveram um caráter social ou coletivo, como o que ocorreu entre os vizinhos. Esta limitação impacta até hoje a vivência do legado constituído, que coabita - em sua manifestação pública sublimada - com a experiência íntima dos familiares e sobreviventes daqueles eventos traumáticos, como compilado neste estudo. ${ }^{7}$

O processo psicológico do familiar de um desaparecido político envolve tensões muito peculiares, como revelado no documentário "Vala Comum", por Felícia Mardini de Oliveira, mãe de Ísis Dias de Oliveira, guerrilheira da Ação Libertadora Nacional (ALN) ${ }^{8}$, desaparecida em janeiro de 1972. Felícia destaca o papel ambivalente da ausência do corpo, por um lado, que a apartava de uma experiência de choque, enquanto de outro acarretava uma angústia constante:

5 Comissão Nacional da Verdade (doravante CNV). Relatório da Comissão Nacional da Verdade. Brasília/DF, Presidência da República, 2014, vol. I, 976p. e Vol. II, 402p.

6 Para uma visão crítica da CNV e das políticas de memória e reparação, ver Teles (2011) e Quinalha (2015). Para uma visão mais positiva, ver Montenegro; Rodeghero e Araújo (2012); Weichert (2014); entre outros.

7 Os testemunhos compilados nesta seção do texto compõem minha dissertação de mestrado. Os principais critérios utilizados para a seleção da amostragem do grupo entrevistado foram os de idade e envolvimento direto na militância da Comissão de Familiares de Mortos e Desaparecidos Políticos desde os anos 1970 ou do Grupo Tortura Nunca Mais, do Rio de Janeiro, a partir dos anos 1980 (Teles, 2005, p. 25-6). Estas entrevistas encontramse disponíveis para consulta no arquivo do Instituto de Estudos sobre a Violência do Estado (IEVE).

8 A ALN foi uma organização de inspiração marxista-leninista criada em 1967, cujo principal líder era Carlos Marighella, líder comunista desde os anos 1930. Atuou na luta armada contra a ditadura, advogando a revolução socialista, a ser realizada em duas etapas no Brasil, sendo a primeira democrático-burguesa. Em 1971, surge a dissidência da ALN denominada Movimento de Libertação Popular (Molipo). A organização tenta um recuo em 1973 em direç̃o ao "trabalho de massas", mas novas prisões e mortes desarticulam-na em maio de 1974 (Ridenti, 1993, p. 31-2) e (Arquidiocese de São Paulo, 1988, p. 44-9). 
"Eu pensava: não vi, então não vou sofrer tanto, mas foi pior, porque fica uma angústia que não termina nunca, principalmente, porque a gente fica pensando que ela morreu sob tortura". ${ }^{9}$

A falta de incentivo para uma expressão social da angústia e do luto torna determinadas experiências, como as de Felícia, particularmente áridas. O trauma que emerge dos testemunhos aqui analisados recebe o contorno de feridas na memória; sua cicatrização é incerta, pela inexistência de subsídios para transpor a subjetivação silenciosa. Familiares e sobreviventes precisam lidar constantemente com "a resistência à transposição (tradução) do inimaginável para o registro das palavras" (Seligmann-Silva, 2003, p. 50). Nesse sentido, o testemunho é constituído, por vezes, da resistência à sua compreensão, a qual se manifesta por meio das narrativas sobre os fatos violentos.

Esta resistência produz uma repetição discursiva e um choro intenso, como evidenciado ao longo da pesquisa na qual se baseou este artigo. A partir de um ponto de vista psicológico, é possivel afirmar que a repetição opera como um sintoma da impossibilidade de traduzir os complexos meandros da experiência vivida, bem como a reminiscência angustiada da tentativa de uma preparação para aquele momento. Já o choro transcende o caráter meramente sintomático, refletindo frustrações e tristezas, atualizadas pela evocação das experiências.

O trauma configura-se psicologicamente como um agregado de representações mentais de alta densidade e baixo potencial para a produção de articulações saudáveis com a totalidade da vida mental. Deste modo, o trauma emerge na consciência de maneira involuntária, da mesma forma como influencia, inconscientemente, as visões construídas sobre o real. Assim, o trauma histórico conta com certas peculiaridades em sua formação, que indicam que ele só pode ser tratado por intermédio de esforços coletivos de simbolização.

No Brasil, contudo, predominam o silêncio e o esquecimento, concernentes aos crimes da ditadura. Os familiares enfrentam dificuldades para encontrar os restos mortais de seus parentes, ter acesso e conhecimento acerca das circunstâncias das mortes, e punir os responsáveis. Esforços coletivos de simbolização são, sob uma perspectiva institucional, insuficientes, permanecendo restritos às lutas dos sobreviventes e das vítimas para romper com a indiferença, de modo a superar a ausência de vínculos e de significados, conforme sublinhado por Ângela Mendes de Almeida. Companheira de Luiz Eduardo da Rocha Merlino, militante do Partido Operário Comunista (POC) ${ }^{10}$ assassinado sob tortura em 1971 (Almeida et al., 2009, p. 259-62), ela relata como vivenciou a angústia associada ao silêncio sobre o passado com que se deparou, ao retornar do exílio:

Nesse período, [os cinco anos de militância clandestina], tinha a sensação de que deveria fazer isso por ele, que a melhor coisa que podia fazer pela memória dele era continuar militando, sentia isso como uma obrigação.

9 Vala Comum. Direção de João Godoy. São Paulo, 1994 (39 min.). Este documentário exibe depoimentos de familiares de desaparecidos políticos, alguns dos quais foram identificados entre as ossadas encontradas no cemitério de Perus.

10 Organização que combateu a ditadura, visando a revolução socialista no Brasil. $\bigcirc$ partido se originou da fusão da POLOṔ (Política Operária) com a Dissidência Leninista do PCB gaúcho, em 1968. Ao decidir se enveredar pela luta armada, alguns militantes resolvem constituir a nova POLOP, em 1970. Duramente atingido pela repressão em 1971, seus remanescentes se dirigem ao exílio, aproximando-se do Movimiento de Isquierda Revolucionario (MIR), no Chile, e do Ejercito Revolucionario Popular (ERP), na Argentina, onde alguns de seus militantes tornam-se desaparecidos (Arquidiocese de São Paulo, 1988, p. 72-3) 
Para que aquilo não fosse sem sentido, porque quando cheguei ao Brasil, as pessoas me disseram que aquilo foi em vão, outras se mostraram indiferentes, foi um choque muito grande para mim. [...] tudo parecia mais distante do que quando eu estava no exílio. Foi aí que me 'exilei' no Rio de Janeiro. ${ }^{11}$

Nos relatos dos familiares, emergem também diversas referências ao sentimento de culpa, por terem sobrevivido, sem ter conseguido evitar as mortes e os desaparecimentos. As perseguições e o terror vivido no país naquele período impuseram obstáculos às buscas por informações dos parentes desaparecidos, conforme testemunho de Suzana K. Lisbôa, integrante da ALN e esposa de Luiz Eurico Tejera Lisbôa, desaparecido em setembro de 1972, na capital paulista (Almeida et al., 2009, p. 367-371). No final de 1971, o casal retornou de Cuba, onde haviam realizado treinamento de guerrilha. De acordo com seu relato, voltaram a morar em Porto Alegre, para reorganizar a ALN no Rio Grande do Sul:

fui para São Paulo para ficar um mês [...]. Viajei no dia 18 de junho de 1972, nesse período, não conseguimos descobrir de onde vinha um "seguimento" [da repressão], então, desmobilizamos tudo o que poderia ter ocasionado o "rabo". Em função disso, tive que abandonar a pensão onde estava. [...] Enviei uma carta [para uma caixa postal] dizendo para o Ico [Luiz Eurico] que não poderia chegar na data prevista etc. [...] Esses dias foram de uma angústia muito grande. Sentia-me mal de pedir para sair de casa [onde ficamos escondidos], porque era mais um transtorno. Por fim, consegui ir para o Rio Grande do Sul e [...] acabei sabendo que ele tinha viajado para São Paulo. Ele viu a notícia da 'queda' do José Júlio ${ }^{12}$ e alertou meu irmão de que viria atrás de mim. [...] Na primeira semana de setembro de 1972 ocorreram os últimos contatos dele. [...] Depois, desapareceu. [...] Vivi durante muitos anos com um peso de chumbo na consciência por ele ter morrido me procurando. Vivi com uma sensação muito ruim de não ter pressionado mais para sair daquela casa, para escrever e antecipar meu retorno. Eu tinha certeza de que ele tinha recebido minhas cartas. [...] Isso é tão complicado [...] Não fui eu que o matei, é claro, mas é uma circunstância difícil de administrar. Mesmo na clandestinidade [...] voltei várias vezes ao sul para procurar o Ico. Viajei atrás de alguns contatos dele, tentando reconstituir o que poderia ter acontecido. [...] procurando notícias dele. ${ }^{13}$

Muitos familiares e sobreviventes convivem com esse sentimento de culpa. No entanto, alguns desestruturaram-se, pois não conseguiram lidar com a morte ou com o desaparecimento

\footnotetext{
11 Ângela Mendes de Almeida. Entrevista concedida a Janaina de A. Teles. São Paulo/SP, em 14/05/2004. A família de Merlino moveu duas ações contra o coronel reformado do Exército Carlos Alberto Brilhante Ustra, chefe do DOI-Codi/SP (1970-1974). Cf. Campanha Merlino mais do que nunca Presente. Nossos Mortos estão vivos em nossas lutas. São Paulo: Coletivo Merlino Presente, 2012.

12 José Júlio, militante da ALN preso e assassinado, sob tortura, no DOI-Codi/SP, em 18/08/72 (Almeida, 2009, p. 364-67).

13 Suzana K Lisbôa. Entrevista concedida a Janaína de A. Teles. São Paulo/SP, em 17 e 21/02/2005.
} 
de seus parentes. O pai de Alceri Maria Gomes da Silva, militante da Vanguarda Popular Revolucionária (VPR) ${ }^{14}$ assassinada ao lado de Antônio dos Três Reis de Oliveira em maio de 1970 (ambos enterrados no cemitério de Vila Formosa), adoeceu e morreu menos de um ano depois. Valmira não suportou o impacto da morte de sua irmã e cometeu suicídio (Almeida et al., 2009, p. 195-97).

Para esses familiares, o desaparecido é alguém que, mesmo morto, ainda vive. Manter a esperança de ter a pessoa viva significa, com frequência, a preservação de sua memória, mas ao mesmo tempo implica também em um prolongamento da agonia. Perpetuam-se uma desestruturação emocional e social insuportável. Nos relatos de familiares há diversas referências ao "vazio" deixado pelos parentes mortos ou desaparecidos, conforme o testemunho de Carmen Navarro Rivas, mãe de Hélio Luiz Navarro de Magalhães, militante do PC do B desaparecido na Guerrilha do Araguaia em março de 1974:

Para mim é muito difícil, é uma dor imensa. A vida da minha família modificou-se por causa dessa tragédia. [...] Houve uma dissolução da família. Realmente, é uma dor imensa que custo muito a me refazer. Tentei escrever alguma coisa sobre meu filho, do meu sentimento, mas choro muito. O sofrimento é maior do que eu possa escrever ou processar mentalmente. Então, procuro, até hoje, através de advogados e pessoas amigas, obter algum relato sobre ele, o que acho que é meu direito de cidadã brasileira. Mas isso, parece, ninguém respeita. Os processos se iniciam e a resposta é "nada consta". Enfim, estou vivendo no completo desconhecimento sobre o meu filho. Desconhecimento significa o seguinte: a tela está em branco. Se a tela está em branco você pode pregar nessa tela o que você quiser. Então, ele está morto? Está vivo? É um morto-vivo? É um vivo morto? São perguntas que carrego há 35 anos e não obtenho nenhuma resposta [...]. Por isso, tenho este vácuo dentro de mim. É um vácuo enorme. Tudo pode ter acontecido e nada sei [...]. Isso me revolta muito como mãe, como brasileira, como professora. [...] São dois os filhos que tenho. Mas o Hélio [...] sempre foi uma voz dentro da casa dele. E, por isso, deixou uma saudade imensa, deixou um silêncio imenso. Até o seu violão está mudo. Tenho o violão, o piano e vários instrumentos musicais que ele tocava muito bem e estão todos mudos. Isto é desesperador e desestrutura as famílias. ${ }^{15}$

Os testemunhos dos filhos de desaparecidos políticos retratam, de maneira ainda mais dramática, a complexidade do trabalho de luto nestas circunstâncias. Eles devem lidar com a figura dos pais que não conheceram, cujas imagens de heróis se tornam grandiosas

${ }^{14}$ A VPR foi um grupo de resistência armada à ditadura militar, visando à instauração do socialismo no Brasil. Formou-se em 1967, desde a união de dissidentes da POLOP com remanescentes do Movimento Nacionalista Revolucionário (MNR). A VPR compôs uma fusão com integrantes do Comando de Libertação Nacional (Colina), dando origem à VAR-Palmares (Vanguarda Revolucionária Palmares). Em 1970, a VRP se reconstrói, mas, em 1973, finaliza suas atividades, após sofrer severas baixas (Arquidiocese de São Paulo, 1988, p. 57-61).

${ }^{15}$ Carmen Navarro Rivas. Entrevista concedida a Janaína de A. Teles. Rio de Janeiro/RJ, em 02/03/2005. Destaques da autora. O pai de Hélio Navarro era almirante e, seu tio chegou a ser ministro da Marinha durante a ditadura (Leitão, 2009). 
e pesadas. Tessa Lacerda, filha de Gildo Macedo Lacerda, militante da AP-ML (Ação Popular Marxista-Leninista) ${ }^{16}$ e vice-presidente da $\mathrm{UNE}^{17}$ (1969-1970) assassinado sob tortura na capital pernambucana, em outubro de 1973, relatou seu sofrimento:

Sempre tive essa visão de que não é justo, não dá para aceitar essa... quer dizer... É difícil falar... Tirar assim a vida... o governo... é difícil falar isso [...]. E tentar construir essa imagem [do meu pai], porque não sei nada. Eu não sei como meu pai era, não sei as coisas mais banais. Eu sei o que ele fez e sempre, na minha cabeça, fica uma coisa grandiosa de herói, porque, afinal de contas, ele morreu por um ideal. Ele estava disposto a isso, enfim, fica aquela coisa gigantesca que até me oprime um pouco. [...] E, até hoje, é muito difícil você aceitar uma morte que não é material, que você não tem... mais que isso, mais que essa imaterialidade da morte, para mim, [há] a imaterialidade da vida, porque eu não tenho... não conheci meu pai. Então, é absolutamente 'pirante', você tentar, por um lado, imaginar como seu pai era e, por outro, aceitar que isso que você imaginou, morreu. ${ }^{18}$

A morte de Gildo se tornou menos concreta, na medida em que a família recebeu seu atestado de óbito, mas não seus restos mortais (Almeida et al., 2009, p. 484-88). O "vazio" deixado pelos desaparecidos, registrado nos testemunhos dos familiares, e o intenso esforço, descrito por Tessa, de imaginar como era seu pai e, ao mesmo tempo, ser obrigada a aceitar que o imaginado não existe, remete à situação descrita por Maria Rita Kehl: a precocidade dessas perdas deixa "apenas a moldura vazia do ideal para o sujeito se identificar" (Kehl, 2005, p. 38). O esforço de imaginar ou de não esquecer, para manter em cena, no presente, este outro que se foi prematuramente, é comum a todos os familiares, favorecendo que se crie "em seu lugar uma espécie de bela casca vazia", própria da idealização (Kehl, 2005, p. 39).

O vazio da ausência acompanha o esforço de imaginar como teria sido se ele/a estivesse vivo, possibilidade que não se esquiva da dificuldade de imaginá-lo vivo ou morto. A dor profunda e a recusa do luto podem fazer com que uma mãe mantenha o quarto do filho intacto desde 1969, como fez Carmen Navarro Rivas. ${ }^{19}$ Diversas mães e pais mantêm o endereço, número de telefone, roupas e mobília de seus parentes desaparecidos, na espera de seu retorno. O quarto de Hélio Navarro se confirgura, assim, em uma tumba, na qual Carmen mantém vivo o filho. De certa forma, trata-se de uma busca por preencher a "tela em

${ }^{16}$ Criada em 1962, desde a atuação de militantes da Juventude Universitária Católica (JUC) e de outros grupos da Ação Católica Brasileira. Defendia o "socialismo humanista"; era composta principalmente de lideranças estudantis, mas contou também com líderes camponeses e operários. A AP sofreu cisões e duros golpes da repressão entre 1972 e 1974, mas seus remanescentes reestruturaram-se ao lado do Movimento Revolucionário 8 de Outubro (MR-8), contribuindo para a reorganização do movimento estudantil a partir de 1976 (Arquidiocese de São Paulo, 1988, p. 33-8)

17 A União Nacional dos Estudantes foi criada em 1937, a fim de unificar as lutas estudantis, ocupando a partir de então um expressivo papel na política brasileira. Foi duramente atingida pela repressão após 1964, mas conseguiu se manter graças a uma estrutura organizativa paralela à oficial. Contribuiu decisivamente nas lutas pela redemocratização do país, sobretudo a partir de 1976 (Arquidiocese de São Paulo, 1988, p. 167-71).

18 Quinze Filhos. Vídeo. Direção de Maria Oliveria e Marta Nehring. São Paulo, 1996 (20 min.). Trata-se de um documentário que apresenta depoimentos de filhos de mortos, desaparecidos e presos políticos do período ditatorial no Brasil.

${ }^{19}$ Com esperança de encontrar o filho com vida, Rivas manteve regularizado seu pagamento de imposto de renda, seu CPF e uma conta no banco em seu nome até 2004 (Leitão, 2009). 
branco", criada pelo desaparecimento. Este quarto se assemelha a uma tumba vazia, a exigir o reconhecimento do luto, negado pelo Estado e pela sociedade.

No luto, a energia está concentrada na cicatrização da ferida, é o tempo de reconstituição da identidade/personalidade dos familiares e sobreviventes, após uma perda ou fracasso. Contudo, no Brasil, o trabalho de luto desses familiares torna-se interminável, devido à manutenção do segredo em torno dos crimes da ditadura. As lutas e memórias dos familiares evidenciam os problemas associados ao desconhecimento da história, lacuna que afasta a sociedade das experiências e lembranças de um passado recente, o que dificulta enormemente uma simbolização coletiva dos traumas históricos.

Diante desse vazio imposto e do confisco da própria história, inventar ou imaginar como seria a vida da pessoa perdida, imaginar para além da existência aprisionada no passado, faz-se necessário ou inevitável, ao familiar e sobrevivente. Eventualmente, neste vazio está localizada a confirmação imaginária da "perfeição" dos mortos e desaparecidos políticos, o que desvaloriza os ganhos dos que sobreviveram, por vezes gerando uma profunda sensação de impotência e fracasso. Na melancolia, a recusa da perda transforma-se também em identificação daquele que sobreviveu com o morto, gerando uma perda de amor-próprio (Jelin, 2002, p. 15), quando "a sombra" daquele que se foi - uma imagem idealizada - "recai sobre o eu". ${ }^{20}$

Ao identificar-se com aquele que se perdeu, o sujeito, de certa forma, o mantém vivo, em sua interioridade. A identificação é a manifestação de um desejo de ter algo em comum com o outro, operação "na qual o eu incorpora alguns traços do objeto perdido de modo a seguir amando em si mesmo o que lhe restou da lembrança de um outro" (Kehl, 2005, p. 3637), própria do luto. Entretanto, por vezes o sujeito sucumbe à identificação. Esta situação emerge nos relatos dos filhos, conforme o testemunho de Tatiana Roque, filha de Lincoln Bicalho Roque, dirigente do Partido Comunista do Brasil (PC do B $)^{21}$ assassinado em tortura, em março de 1973. Por um tempo, pode parecer à mãe, ao filho ou à esposa, que não tenha sido capaz de se fazer amar, de modo que a militância política do pai ou do parente assassinado é referida como abandono:

Para mim, meu pai era um herói, mas [...] eu tinha a sensação de que ele havia me abandonado. Outras pessoas disseram que ele poderia ter se exilado se quisesse, mas ele não queria. A sensação, em mim, era de que, se quisesse, ele poderia ter ficado comigo. Era a revolução ou eu, ou seja, uma escolha. ${ }^{22}$

Os filhos enfrentaram obstáculos particularmente espinhosos para lidar com o

\footnotetext{
${ }^{20}$ Nas palavras de Freud (1999, p. 95): "a sombra do objeto caiu sobre o ego, e este pôde, daí por diante, ser julgado por um agente especial, como se fosse um objeto, o objeto abandonado". De acordo com Nasio (1997, p. 108 e 170), "Mais do que decompor, caberia dizer que a sombra do objeto divide o eu em duas partes, com uma parte fora da sombra - chamada supereu - enfurecendo-se contra a outra parte que permaneceu na sombra, identificada com o objeto perdido".

${ }^{21}$ O PCdoB surgiu de uma dissidência do PCB, em fevereiro de 1962, decidindo-se por reeditar o jornal "A Classe Operária", fundado em 1925. Influenciado pelo projeto chinês de "guerra popular prolongada", advogava que o processo revolucionário brasileiro teria na área rural seu principal palco de luta. Sofreu dissidências e duros golpes da repressão, sobretudo contra a Guerrilha do Araguaia (1972-1974). Em 1978, desvinculou-se publicamente do maoísmo e do PC Chinês, aproximando-se da Albânia (Arquidiocese de São Paulo, 1988, p. 29-33).

22 Tatiana Maria Lourdes Roque. Entrevista concedida a Janaína de A. Teles. Rio de Janeiro/RJ, em 11/04/2004.
} 
desaparecimento ou a morte abrupta dos pais, como oconteceu com Ñasaindy Barrett de Araújo. Nascida em Cuba, ela perdeu o pai e a mãe - José Maria Ferreira de Araújo, assassinado em tortura em setembro de 1970, e enterrado na vala de Vila Formosa, e Soledad Barrett Viedma, assassinada em janeiro de 1973, no Massacre da Chácara São Bento. Ambos integravam os quadros da VPR e foram alvos da delação de Cabo Anselmo, um marinheiro que atuou como agente policial infiltrado na organização. Ñasaindy foi adotada no exílio, em Cuba, pela família de Damaris Oliveira Lucena, cujo marido, Antonio Raymundo de Lucena havia sido assassinado pelos órgãos de segurança em 1970 e enterrado na vala de Vila Formosa (Almeida et al., 2009, p. 181-82). De acordo com seu testemunho, ela não possui lembranças dos pais,

\begin{abstract}
Mas, nos meus processos terapêuticos, vamos dizer assim, tive oportunidade sim de me encontrar com o que seria o momento de despedida da minha mãe. E [...] nesse momento eu escolhi morrer. No momento em que perdi a minha mãe ou na minha despedida, quando soube que não veria mais a minha mãe, mesmo estando no colo de uma pessoa que eu já amava, eu queria morrer. $E$ isso eu fiquendo sabendo depois [com 10 anos]. E durante toda a minha vida, e talvez até hoje seja o que eu ainda quero. Então, é muito difícil para a gente lidar. E tem a forma como ela foi assassinada, todo esse cenário, isso tudo também, de alguma forma faz a gente tocar nessa questão da violência. É muito forte... (Araújo, 2014, p. 102).
\end{abstract}

De fato, a perda abrupta e violenta acentua o sentimento de abandono, muitas vezes não declarado, mas presente nas referências recorrentes ao vazio e desamparo. Essa identificação com os mortos se apresenta nas palavras e nas lutas das mães, como a famosa estilista Zuzu Angel, que registrou em seu livro autobiográfico que buscava substituir o filho, na luta contra a ditadura (Valli, 1987); ou das companheiras que continuaram a luta revolucionária dos maridos assassinados e desaparecidos.

Paralelamente, a distinção entre sobrevivente e familiar se matiza, e perde-se, à luz das contingências impostas pela ditadura. É de se ter em vista que alguns familiares passaram por cárceres, torturas, exílio e ameaças de morte; outros perderam suas vidas, na busca por informação e justiça. Eliminação física e simbólica, mais de uma vez fundiram-se no Brasil. Tal foi o caso de Zuzu Angel, mãe do estudante de Economia e guerrilheiro do Movimento Revolucionário 8 de Outubro $(M R-8)^{23}$, Stuart Angel Jones, torturado até a morte na base aérea do Galeão, no Rio de Janeiro, para que entregasse a localização do capitão Carlos Lamarca (que morreu meses depois, em uma perseguição épica no interior da Bahia), cujo corpo permanece desaparecido desde maio de 1971 (Almeida et al., 2009, p. 246-48 e 277-81).

${ }^{23}$ A organização surgiu da Dissidência Comunista de Niterói (DI-RJ), uma cisão do PCB, denominada MR-8 a partir de 1967. Atingido pela repressão no início de 1969, seus remanecentes se uniram aos militantes da DI da Guanabara, organizando o novo MR-8. Atuou na guerrilha urbana, assumindo um papel de destaque em sequestros de diplomatas. Duramente atingida pela repressão, a organização sofre cisões no exílio. Após o golpe no Chile, um grupo de remanscentes estabelece a autocrítica da luta armada e se propõe a organizar uma frente de esquerda e retornar ao Brasil, a partir de 1974. No país, assume uma atuação de destaque na redemocratização (Arquidiocese de São Paulo, 1988, p. 53-6). 
Zuzu Angel empreendeu uma campanha internacional de sucesso, dirigida à divulgação do desaparecimento de Stuart, que possuía dupla cidadania (norte-americana/brasileira). Em 1971 ela realizou um notório desfile de moda nos Estados Unidos, que escandalizou a audiência, com referências explícitas à repressão no Brasil e ao filho desaparecido. Infelizmente, o sucesso de sua campanha e o poder subversivo do testemunho de Zuzu Angel acarretaram seu assassinato pelo aparato repressivo, o qual forjou um acidente de carro no Rio de Janeiro, em abril de 1976, elucidado apenas em 1996 (Almeida et al., 2009, p. 649-51).

Nesse contexto, aos familiares somente é permitido lembrar a ausência, reacendendo permanentemente a lembrança dessa presença ausente, bem como o desejo de libertar-se de um passado que continua presente (Adorno, 1995). O desaparecimento, a falta de um corpo, de um momento de luto e de uma sepultura assumem tal dimensão que, mesmo passados muitos anos dos fatos, impossibilitam a emergência de representações de um corte, de um antes e um depois, e o trabalho de luto (Catela, 2001, p. 150; Seligmann-Silva, 2000, p. 85-93).

$O$ testemunho dos familiares e sobreviventes, conforme indicado nos registros aqui compilados, é caracterizado por traços de um luto interminável, cuja compreensão depende de uma abordagem histórica, devido à persistência desse passado "que não passa" (Rousso, 2007), e da ausência de esforços consistentes de sua simbolização coletiva. A seguir, serão abordados os processos de constituição das memórias do período ditatorial no Brasil.

\section{Brasil: Nunca Mais e a vala de Perus: a emergência das memórias da ditadura}

A transição brasileira para a democracia ocorreu sem rupturas evidentes, pautada pela conciliação entre as elites civis e militares, depois de asseguradas as condições de que o passado não seria remexido profundamente. Esse pacto limitou a apuração dos crimes da ditadura, a responsabilização de seus autores e a constituição das memórias sobre o período. Não obstante, alguns atores sociais buscaram exibir marcas simbólicas e efetivas de rompimento com o período anterior, sistematizando e divulgando as denúncias dos crimes da ditadura, tendo em vista propostas e mecanismos de recuperação factual e judicial, bem como das memórias referentes a esses fatos (Teles, 2005 e 2011).

As transições políticas influenciam a construção do legado do regime político anterior, na medida em que esses momentos de mudança na relação entre Estado e sociedade representam "atos fundacionais", nos quais se apresentam conflitos entre novas e velhas leituras do passado (Jelin, 2002, p. 43-44). No Brasil pós-ditadura, as disputas pelas memórias foram pautadas por dois marcos inaugurais: a publicação do relatório do projeto "Brasil: Nunca Mais" (doravante, BNM) ${ }^{24}$, em 1985, e a abertura da vala clandestina de Perus, em 1990 (Teles, 2012).

${ }^{24}$ Entre 1979 e 1985, o projeto copiou secretamente 707 processos encontrados nos arquivos da justiça militar desde 1964, reunindo 1,2 milhão de páginas de documentos produzidos pelo aparato repressivo ou por ele apropriado de grupos dissidentes. Ver Brasil: Nunca Mais digital, disponível em: <http://bnmdigital.mpf.mp.br/ $\mathrm{pt}-\mathrm{br} />$. Acesso em: 18/05/2017. 
A publicação do livro Brasil: Nunca Mais ${ }^{25}$ inaugurou as operações de memória sobre a repressão da ditadura no período de transição para a democracia. Esta obra favoreceu a constituição de uma consciência coletiva acerca da política repressiva do período e do status dos sobreviventes. Baseado nessa vasta documentação, o livro pôde ser instrumentalizado para a formação escolar e acadêmica, assim como para a sistematização de denúncias de abusos dos direitos humanos (Capelato, 2007, p. 14-17), ao longo dos últimos 40 anos. Parte desse processo foi possível porque uma parcela dos perseguidos políticos submetidos aos "tribunais de exceção", controlados pela justiça militar desde 1965, efetuou declarações em juízo que continham denúncias das torturas sofridas, nas quais mencionavam os nomes dos torturadores e os métodos de sevícia empregados. ${ }^{26}$ Desse modo, a ditadura documentou parte das violações aos direitos humanos que praticava, mantendo esses documentos em arquivo no Superior Tribunal Militar (doravante, STM). Não obstante, o caráter oficial da documentação e, principalmente, sua origem nos tribunais da ditadura forneceram informações com certas características, que pouco acrescentaram ao esclarecimento dos assassinatos sob tortura, sobretudo no que tange aos desaparecimentos forçados.

O BNM refletiu as ambiguidades e os limites da transição política brasileira, que, todavia, marcam a construção das memórias sobre a ditadura. Inicialmente, a equipe do projeto adiou a publicação do livro, até o momento posterior à posse do presidente civil, eleito indiretamente pelo Congresso Nacional, tendo em vista a insegurança do ambiente político e a permanência da vigência das "Salvaguardas de Emergência". Com a doença de Tancredo Neves, o lançamento do livro foi adiado para 15 de julho, quando finalmente chegou às livrarias (Weschler, 1990, p. 75).

O projeto BNM representou um empecilho ao acobertamento dos crimes da ditadura, ainda que seus desdobramentos políticos e institucionais tenham sido tímidos. A despeito das consequências práticas limitadas, os ecos traumáticos das denúncias das violações compiladas no BNM desempenharam papel decisivo na percepção da sociedade civil, acerca da extensão dos crimes cometidos pela ditadura, assim como por sua condenação moral. Esta percepção tem contribuído para a limitação do poder e do espaço concedido às Forças Armadas, no âmbito do aparato burocrático do Estado. A contribuição do BNM é a de possibilitar à sociedade brasileira lidar com o legado da ditadura, do ponto de vista jurídico, histórico e cultural.

O segundo ato memorialístico fundamental sobre a repressão da ditadura no Brasil foi a abertura da vala clandestina de Perus, em setembro de 1990. Esse evento teve por objetivo a busca de restos mortais de militantes assassinados por órgãos de segurança daquele período, ganhando ampla repercussão junto à opinião pública, com efetivas consequências nas investigações daqueles crimes (Teles, 2012).

Em 1979, familiares de mortos e desaparecidos políticos descobriram pistas a respeito de dissidentes enterrados com nomes falsos no cemitério Dom Bosco, em Perus. Em 22 de

25 O resumo do relatório final desse projeto foi transformado em livro. Cf. Arquidiocese de São Paulo. 22ª. ed. Brasil: Nunca Mais - um relato para a história. Petrópolis/RJ: Vozes, 1989. 312p.

${ }^{26}$ Mesmo sob ameaça de novamente sofrer torturas, 1.843 pessoas (25\% dos réus) revelaram as torturas às quais foram submetidas durante a ditadura militar e os assassinatos que testemunharam (Arquidiocese de São Paulo, 1989, p. 25). 
agosto daquele ano, dia da votação do projeto de lei de anistia, eles divulgaram a localização da sepultura de dois desaparecidos: Dênis Casemiro ${ }^{27}$ e Luiz Eurico Tejera Lisbôa. Em plena ditadura, enquanto o governo buscava controlar o protesto popular impondo uma anistia parcial, os familiares denunciavam os crimes do regime. A despeito da repercussão dessas denúncias, a investigação desses crimes não prosperou. Não obstante, durante as buscas os familiares descobriram a existência de uma vala clandestina, que conteria os restos mortais de militantes assassinados por órgãos de segurança. As estruturas do aparelho repressivo da ditadura, porém, permaneciam intactas, impossibilitando a apuração da denúncia.

Entraves políticos dificultaram o enfrentamento dessa questão, mas logo após a abertura da vala clandestina, iniciaram-se as escavações e as pesquisas de antropologia forense, que foram acompanhadas pela instauração de uma Comissão Parlamentar de Inquérito (doravante, CPI) na Câmara Municipal de São Paulo em 1990, visando apurar o que ocorreu em Perus e nos demais cemitérios da cidade. A abertura da vala propiciou a descoberta de outras valas com restos mortais de militantes assassinados no Rio de Janeiro e em Pernambuco, e a realização de escavações arqueológicas na cidade e em outros estados.

Por seis meses, a CPI buscou desvelar os mecanismos pelos quais se tornou possível a manutenção, em segredo, das 1.049 ossadas na vala de Perus, desde 1976. O trabalho de investigação obteve informações sobre as formas como os militares, a polícia e os médicos legistas do Instituto Médico Legal se articularam para ocultar os cadáveres e suas respectivas causa mortis. O BNM já havia denunciado sua participação na falsificação de laudos necroscópicos e ocultação de cadáveres para acobertar marcas de tortura, mas pouco se sabia. As investigações da CPI evidenciaram o esquema dirigido a falsificar os laudos e enterrar militantes com nomes falsos, em cemitérios de São Paulo.

Em São Paulo havia uma determinação para que as autópsias fossem mantidas em sigilo. Essas obedeciam a um ritual próprio, envolvendo sempre os mesmos funcionários, realizadas em sessões noturnas. Uma lista restrita de legistas fazia escala para realizar este trabalho. Outra especificidade na condução dessas autópsias consistia em fotografar apenas a cabeça. A determinação do registro fotográfico para mortes violentas, exigência da lei, foi burlada por ordem direta do comandante do DOI-Codi/SP28, Carlos Alberto Brilhante Ustra, com a finalidade de não expor as demais partes dos corpos marcados pela tortura. ${ }^{29}$ Diante de sinais evidentes de tortura, era frequente que o legista descrevesse uma parcela considerável das marcas decorrentes de sevícias. Contudo, ao final, ele corroborava a versão policial. Como resposta ao quesito no. 4, relativo à existência de tortura, frequentemente o legista assinalava: "prejudicado", de maneira a omitir-se de efetuar conclusões, a partir de suas observações

27 Militante da VPR, Dênis desapareceu em 18/05/71. Seus restos mortais foram enterrados na vala clandestina de Perus e identificados pelo DML/Unicamp, em 13/08/91 (Almeida, 2009, p. 249-51).

28 O Destacamento de Operações de Informação - Centro de Operações de Defesa Interna foi criado em 1970 , combinando serviços de informação e repressão, composto por órgãos dos três ramos das Forças Armadas e pelas Polícia Civil, Federal e Militar, subordinado ao Exército. Destinado a combater o "inimigo interno", sua filosofia de atuação era pautada pela Doutrina de Segurança Nacional, formulada nos Estados Unidos e aprofundada na Escola Superior de Guerra, a partir de 1949 (Teles, 2011, p. 88-9).

${ }^{29} \mathrm{O}$ DOI-Codi/SP e o DEOPS/SP organizaram o sistema de ocultação de provas do uso sistemático de torturas e de cadáveres de militantes assassinados, cf. a conclusão da investigação da CPI sobre a Vala de Perus (Caligiuri Filho, 1992, p. 22 e 41). 
(Teles, 2017, p. 86).

Muitas dessas mortes ocorreram em centros especializados em torturas, como é o caso do emblemático DOI-Codi/SP, que contava com um grupo especialmente treinado para matar (denominado "GTA" - Grupo Tático Armado), geralmente comandado por um tenente da Polícia Militar. Seu trabalho não apenas incluía a consumação das mortes, como a produção de falsas versões, como "morte em tiroteio", "morte por tentativa de fuga", "atropelamento", "suicídio" ou "acidente de automóvel", que eram frequentemente divulgadas pela imprensa (Teles, 2017, p. 86).

Por vezes, a despeito da notícia das mortes, as forças de segurança desapareciam com esses corpos. As práticas que forjaram versões falsas para os assassinatos de presos políticos e ocultação de seus corpos, alterando os procedimentos do Instituto Médico Legal (doravante, IML) e dos cemitérios de São Paulo, foram documentadas e informam sobre o grau elevado de articulação e controle exercido pelos órgãos de segurança interna do país naquele período. ${ }^{30}$

O mesmo padrão corporativo prevalecia em relação ao transporte dos corpos. Os cadáveres de militantes assassinados enviados do IML para o cemitério de Perus eram geralmente sepultados em horários específicos, com vistas a ocultar a movimentação. Os corpos de militantes eram marcados com a letra "T", indicativo de que eram "especiais" e, portanto, deveriam ser enterrados como indigentes. Embora várias requisições de exame possuíssem anotação indicativa de seus nomes verdadeiros, geralmente, eles eram enterrados com o nome falso, utilizado na militância clandestina. Diversos documentos encontrados nos arquivos do Departamento de Ordem Política e Social (doravante, DEOPS/SP) ${ }^{31}$ confirmaram que os policiais tinham conhecimento de seus nomes verdadeiros (Teles, 2017, p. 87).

A assinatura de um delegado do DEOPS/SP ou da 36ㅁ. Delegacia de Polícia (doravante, DP, na qual funcionava o DOI-Codi) nas requisições constituía indicação de que o corpo deveria ser liberado rapidamente, sem obedecer ao procedimento de mantê-lo em geladeira por 72 horas, à espera de familiares, como determina a lei. O cuidado de guardar sigilo sobre a atuação da repressão política também está registrado nos ofícios do DEOPS/SP enviados ao $I M L$, que autorizavam a retirada de corpos do necrotério, desde que devidamente lacrados (Caligiuri Filho, 1992, p. 24).

Estima-se que pelo menos 19 corpos de dissidentes assassinados foram enterrados no Cemitério Dom Bosco, de Perus. Dentre estes, dez com nomes falsos, sendo que seis deles provavelmente foram conduzidos para a vala clandestina. Essas investigações motivaram outras, de modo que sete ossadas de militantes assassinados durante a ditadura foram identificadas pela Universidade de Campinas (UNICAMP), entre 1992 e 1993. ${ }^{32}$ Nesse período também teve início um Inquérito Policial, na Delegacia Seccional Oeste de São Paulo, para apurar as

\footnotetext{
30 Depoimento do delegado Josecyr Cuoco cedido à CPI sobre a Vala de Perus (Caligiuri Filho, 1992, p. 25 e 41).

31 O DEOPS foi criado em 1924 e atuou como a polícia política do Estado até sua extinção em 1983, em São Paulo, não obstante as diversas modificações pelas quais passou. Ao lado do DOI-Codi, entre outros órgãos, compôs o aparato repressivo brasileiro ao longo da ditadura. Note-se que, as polícias políticas dos demais estados do país adotaram a sigla DOPS.

32 Desses seis militantes enterrados na vala comum, cinco eram considerados "mortos oficiais"', ainda que os familiares não tenham recebido seus corpos.
} 
responsabilidades referentes à vala clandestina. A repercussão nacional desses fatos favoreceu a pesquisa nos arquivos do IML/SP, organizada por familiares de mortos e desaparecidos, o que também ocorreu no Rio de Janeiro. Em 1991, a pedido dos familiares, o presidente Collor promoveu a abertura dos arquivos das polícias políticas, os DOPS. Este processo culminou na criação da Comissão de Direitos Humanos do Congresso Nacional ${ }^{33}$ e na promulgação da Lei dos Mortos e Desaparecidos Políticos (Lei 9.140)³4, em 1995.

Um balanço dessa experiência indica desdobramentos institucionais consistentes, tais como a recomendação para desvinculação do IML da polícia estadual, a reorganização dos cemitérios municipais, a devolução dos arquivos dos DOPS aos estados e a regulamentação da Lei de Arquivos (8.159/91) à Informação ${ }^{36}$ ). Em sentido inverso ao do BNM, que reuniu extensa fonte documental oriunda de registros oficiais sobre os crimes da ditadura, a apuração dos fatos na CPI de Perus envolveu uma rara profusão de depoimentos. Ao todo, a CPI registrou 82 testemunhos de vítimas, médicos legistas, torturadores e agentes da repressão daquele período (Caligiuri Filho, 1992). Acrescente-se que o registro dos depoimentos caminhou lado a lado com a verificação dos dados da pesquisa efetuada em arquivos policiais, como os do IML/SP e do Serviço Funerário Municipal (doravante, SFM/SP) ${ }^{37}$.

As escavações decorrentes da abertura da vala de Perus propiciaram a emergência de algumas das mais emblemáticas memórias referentes à ditadura, reforçando as relações entre memória e atividade arqueológica, sobretudo no que diz respeito aos crimes do Estado de Segurança Nacional. Frequentemente, estudos sobre memória incluem analogias arqueológicas e metáforas de exumação, que se difundiram com os estudos freudianos do inconsciente enquanto camada subterrânea, de difícil acesso direto da mente, estabelecendo aproximações com o caso brasileiro (Freud, 1998).

À comoção gerada pelas imagens de coveiros desenterrando centenas de sacos com ossos, divulgadas nos jornais, TV e cinemas, somaram-se os esforços de familiares, que por muitos anos compilaram dados e divulgaram denúncias sobre esses crimes (Almeida et al., 2009). Note-se que, somente na vala clandestina de Perus, foram encontradas ossadas devidamente armazenadas em sacos plásticos, o que foi fundamental para a realização de identificações. Não obstante, passados quase 27 anos, os trabalhos de identificação dos restos

33 Informação disponível em: <http://www2.camara.leg.br/atividade-legislativa/comissoes/comissoespermanentes/cdhm>. Acesso em 14/05/2017.

34 Informação disponível em: <http://www.planalto.gov.br/ccivil_03/leis/L9140compilada.htm>. Acesso em 14/05/2017. Esta lei de 1995 "previa a possibilidade de reconhecimento da responsabilidade estatal por mortes e desaparecimentos, por motivação política, ocorridos no período compreendido entre 02 de setembro de 1961 e 15 de agosto de 1979". Entretanto, em 2002, a Lei no 10.536/02, publicada no Diário Oficial da União do dia 15/08/2002, ampliou o período de abrangência da lei de 1995, "estabelecendo a responsabilidade do Estado por mortes e desaparecimentos de pessoas que tenham participado, ou tenham sido acusadas de participação em atividades políticas, no período compreendido entre 02 de setembro de 1961 e 05 de outubro de 1988". Cf. <http://www.desaparecidosdobrasil.org/leis-sobre-desaparecidos/leis-e-projetos-de-lei-de-desaparecidos/ lei914095mortosedesaparecidospoliticos>.

35 Disponível em: <http://www.planalto.gov.br/ccivil_03/leis/L8159.htm>. Acesso em: 15/05/2017.

36 Disponível em: <http://www.planalto.gov.br/ccivil_03/_ato2011-2014/2011/lei//12527.htm>. Acesso em 14/05/2017.

37 Secretaria Municipal de Serviços (SMS): Serviço Funerário do Município de São Paulo (SFMSP). Memória \& vida: morte e luto. São Paulo. SES/SFMSP, 2016. 40p. Disponível em: <http://www.prefeitura.sp.gov.br/cidade/secre tarias/upload/memoriaevidapublicacao.pdf>. Acesso em: 18/02/2017. 
mortais encontrados na referida vala não foram concluídos.

\section{A vala clandestina do cemitério de Vila Formosa}

Um dos principais desdobramentos das investigações produzidas pela CPI da Vala de Perus foi a descoberta de documentos remanescentes dos arquivos do IML-SP, que confirmaram as suspeitas de que outros cemitérios foram utilizados para enterrar militantes assassinados no período ditatorial, como o de Vila Formosa e o de Campo Grande. ${ }^{38}$

Antes da inauguração do cemitério D. Bosco, os presos políticos assassinados em São Paulo eram enterrados como indigentes, no cemitério de Vila Formosa, na zona Leste, periferia da cidade. Foram efetuadas requisições de exame necroscópico de alguns militantes que haviam sido assinalados com a letra "T" em vermelho, em alusão à palavra "terrorista". Desde o início de 1969, este era o procedimento adotado pelos órgãos de segurança paulistanos. Estima-se que pelo menos 14 perseguidos políticos tenham sido enterrados nesse cemitério. ${ }^{39}$ A localização de documentos referentes a um prisioneiro político, José Maria Ferreira de Araújo, realizada pela Comissão de Familiares de Mortos e Desaparecidos Políticos, motivou novas investigações. Assim, apurou-se que Araújo tinha sido enterrado com o nome falso de Edson Cabral Sardinha, na sepultura 119 da quadra 11, Cemitério de Vila Formosa. Mudanças na disposição de algumas quadras do cemitério, efetuadas em 1975, impossibilitaram a obtenção de informações sobre os restos mortais de Araújo e demais militantes desaparecidos (Almeida et al., 2009, p. 202). De acordo com a investigação da CPI da Vala de Perus, tais alterações foram realizadas sem projeto, registro ou procedimentos com vistas à futura localização das sepulturas. A área em que estava localizada a antiga quadra 11, conhecida como a quadra dos "terroristas", foi descaracterizada com a alteração do traçado das ruas que demarcavam as quadras. Estas foram alargadas, plantaram-se árvores, que invadiram as áreas reservadas às sepulturas e sobre essas quadras alteradas foram efetuados novos sepultamentos, em sentido diagonal ao antigo, inviabilizando a localização de corpos anteriormente enterrados ali.

Nessa ocasião, a Comissão de Familiares tentou resgatar os restos mortais do desconhecido enterrado como indigente, na mesma data do desaparecimento de Virgílio Gomes da Silva, com procedência da 36ㅁ DP. Esse indivíduo possuía uma requisição de exame identificada com o no 4059/69. Contudo, as buscas foram infrutíferas, em decorrência das mudanças acima mencionadas. Em 2004, porém, o destino dos restos mortais de Silva foi

\footnotetext{
${ }^{38}$ Nesse cemitério foram sepultados Emanuel Bezzerra dos Santos (1943-1973) e Manoel Lisboa de Moura (19441973), militantes do Partido Comunista Revolucionário (PCR). Cf. (Almeida, 2009). Há suspeitas de que o cemitério de Parelheiros também tenha sido utilizado para ocultar restos mortais de perseguidos políticos. Cf. Secretaria de Direitos Humanos (doravante SDH), 2010, p. 129.

39 De acordo com os levantamentos realizados na pesquisa em que se baseia este artigo, 10 militantes permanecem sepultados neste cemitério: Alceri Maria Gomes da Silva, Antônio Raymundo de Lucena, Edson Neves Quaresma, Yoshitane Fujimori, Joelson Crispim, José Maria Ferreira de Araújo, membros da VPR; Antônio dos Três Reis de Oliveira, José Idésio Brianezi, Sérgio Roberto Corrêa e Virgílio Gomes da Silva da ALN. Norberto Nehring, Carlos Marighella e José Idésio Brianezi, militantes da ALN, foram exumados posteriormente, pelas respectivas famílias.
} 
estabelecido pelo jornalista Mário Magalhães, que localizou seu laudo necroscópico e a foto de seu corpo nos arquivos do DEOPS/SP, confirmando seu sepultamento como desconhecido em Vila Formosa, conforme indicava a requisição mencionada.

Essa documentação possibilitou o início de investigações decorrentes de uma ação civil pública sobre as responsabilidades de autoridades pela ocultação de cadáveres de dissidentes assassinados pela ditadura, de autoria do Ministério Público Federal de São Paulo (doravante, MPF/SP), em 2010. A partir da demanda dos familiares de Virgílio Gomes da Silva e Sérgio Roberto Corrêa (ambos militantes da ALN), do Grupo Tortura Nunca Mais (GTNM/SP) e do Sindicato dos Químicos de São Paulo, a ação resultou na elucidação parcial dessa história. Em uma expedição conduzida por representantes do MPF/SP, da Comissão Especial sobre Mortos e Desaparecidos Políticos (CEMDP), do Instituto Nacional de Criminalística do Departamento de Polícia Federal (INC/DPF) e do IML/SP foi descoberta a vala clandestina de Vila Formosa. ${ }^{40}$

Essas investigações acarretaram a descoberta de que a planta original do cemitério incluía a construção de um crematório para indigentes, tal como no cemitério Dom Bosco, em Perus. Descobriu-se que as irregularidades existentes nessa proposta e as tentativas de mudar a legislação, de modo a propiciar essa prática, foram igualmente frustradas, o que resultou na instalação do forno de cremação no Cemitério de Vila Alpina, em 1974. ${ }^{41}$ Tendo em vista essa transferência, a área anteriormente destinada ao sepultamento de indigentes em Vila Formosa foi reestruturada em 1975, sem registro das mudanças nem das providências adotadas quanto aos restos mortais ali sepultados, de maneira similar ao que ocorreu em Perus. Suspeitava-se que os ossos exumados haviam sido depositados em uma vala comum, localizada na entrada do prédio da Administração I, embaixo de um canteiro, no qual havia uma placa informativa do nome do cemitério. ${ }^{42}$

Entre novembro e dezembro de 2010, foram realizadas escavações nas quadras em que, segundo o livro de óbitos, teriam sido inumados Virgílio Gomes da Silva e Sérgio Roberto Corrêa, e na suposta vala clandestina, próxima à entrada do prédio da administração (Weichert e Fávero, 2010). Assim, descobriu-se que cerca de 90 restos mortais, armazenados em sacos plásticos, foram despejados nessa vala, localizada num jardim da rua Flor (Figura 1). Nela encontravam-se ossadas recentes, esquecidas ali desde meados de 2002. Abaixo dessa camada de sacos, havia ossadas datadas da década de 1970, armazenadas de maneira incorreta por longo período de tempo, em avançado estado de decomposição, o que impossibilitou sua identificação. ${ }^{43}$

40 SDH. Habeas corpus: que se apresente o corpo: A busca dos desaparecidos polpiticos no Brasil. Brasília/ DF: Secretaria de Direitos Humanos, 2010. 346p, p. 129. Disponível em: <http://www.dhnet.org.br/verdade/ resistencia/a_pdf/livro_sdh_habeas_corpus.pdf>. Acesso em: 15/03/2017. Sobre o início das escavações de 2010 ver "Ministério Público Federal procura por ossadas de desaparecidos políticos na Vila Formosa". Disponível em: $<$ https://www.youtube.com/watch?v=2J2aqUSkeHc>. Acesso em: 11/01/2017.

${ }^{41}$ Comissão Estadual da Verdade de São Paulo "Rubens Paiva" (doravante, CEV/SP). "Métodos e Técnicas de Ocultação de Corpos na Cidade de São Paulo". In: Relatório da Comissão Estadual da Verdade de São Paulo "Rubens Paiva". São Paulo, ALESP, 2015, Tomo I, Parte I, p. 7, disponível em <http://comissaodaverdade.al.sp.gov. br/relatorio/>. Acesso em: 16/02/2017.

42 CEV/SP, "Métodos e Técnicas de Ocultação de corpos na Cidade de São Paulo", op. cit., p. 7.

43 Os exames periciais e antropológicos foram conduzidos pelo INC e o IML. As análises para identificar Sérgio Roberto Corrêa foram negativas, e as referentes a Virgílio Gomes da Silva não foram adiante, pois não foi possível extrair DNA das amostras disponíveis (CEV/SP, 2015, p.7). 
Figura 1: Ossadas encontradas na vala clandestina do cemitério de Vila Formosa, em 2010

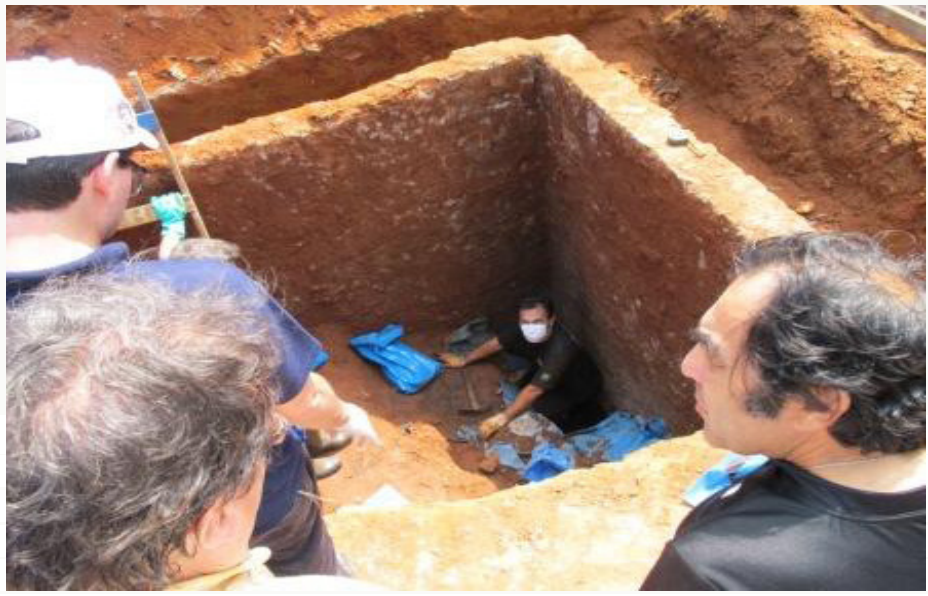

Fonte: Gabinete do ex-deputado estadual Adriano Diogo/SP (2010)

De acordo com o testemunho de Adriano Diogo, ex-presidente da Comissão da Verdade de São Paulo "Rubens Paiva" (2012-2015), que acompanhou as investigações, enquanto presidente da Comissão de Direitos Humanos da Assembléia Legislativa de São Paulo:

foi realmente impressionante encontrar aquelas ossadas e descobrir que isso ocorreu em plena democracia e bem em frente da administração do cemitério. Quando eu achava que estávamos no fim das investigações, percebi que aquilo era apenas o começo. De início, não sabíamos se as ossadas tinham ligação com os presos políticos ou como foram parar na vala, porque não havia registro desses restos mortais em lugar nenhum. Além disso, durante as escavações, percebemos que não existia metodologia e tivemos de encontrar as aerofotos para ajudar, mas no meio daquela confusão foram os coveiros que acabaram indicando o local da vala. É preciso dizer que se deve investigar isso a fundo e punir os responsáveis por esse descaso humano, tanto no período ditatorial quanto na democracia! ${ }^{44}$

Ao longo da investigação, as equipes técnicas rabalharam em duas frentes. Na primeira, atuavam na vala clandestina que abrigava as ossadas do período democrático e da ditadura e, na segunda, atuaram nas chamadas "quadras dos terroristas". Severas críticas foram feitas à condução dos trabalhos e ao Serviço Funerário da capital paulista, então responsável pela administração dos cemitérios, ${ }^{45}$ mas nada foi esclarecido, quanto às ossadas ali depositadas do período democrático.

${ }^{44}$ Adriano Diogo. Entrevista concedida a Janaína de A. Teles. São Paulo/SP, 07/01/2017.

${ }^{45}$ CEV/SP, "Métodos e Técnicas de Ocultação de corpos na Cidade de São Paulo", op. cit., p. 7. 


\section{O Memorial dos Desaparecidos de Vila Formosa}

Em maio de 2013, a partir do crescente debate em torno das heranças da repressão ditatorial no Brasil, a Comissão de Familiares reivindicou a construção de um memorial, dedicado a homenagear as vítimas da repressão ditatorial em Vila Formosa, como havia sido feito no cemitério Dom Bosco, em Perus. A proposta surgiu durante a Audiência Pública realizada pela Comissão da Verdade do Estado de São Paulo "Rubens Paiva" acerca da apuração dos eventos traumáticos, ocorridos nos cemitérios de Perus e Vila Formosa. ${ }^{46}$

A prefeitura de São Paulo, por outro lado, reconhecendo a relevância da investigação sobre os casos de Virgílio Gomes da Silva e Sérgio Roberto Corrêa, propôs que o terreno da "quadra dos terroristas" fosse transformado em local de recordação, criando ali o jardim intitulado "Para não dizer que não falei das flores...", inaugurado em março de 2016, destinado a homenagear os dois militantes. ${ }^{47}$ De acordo com a Secretaria de Direitos Humanos do município, esse projeto instala um marco de memória, com o objetivo de preservar a "memória histórica e [a] construção pública da verdade sobre períodos autoritários" e contribui com o propósito de ressignificar os espaços dos cemitérios enquanto "Parques de Memória e Vida". ${ }^{48}$

A edificação do memorial dedicado aos desaparecidos políticos da vala comum de Vila Formosa, contudo, foi possível, graças ao protagonismo dos familiares. O processo de edifição deste memorial, recente e ainda desconhecido, reflete as vicissitudes enfrentadas por familiares, sobreviventes e defensores dos direitos humanos no Brasil, contrastando com o relevo conquistado pela Comissão Nacional da Verdade e suas congêneres, em período recente. Esse quadro emerge dos relatos dos protagonistas dessa história aqui registrados, conforme testemunho de Criméia de Almeida, companheira de André Grabois, desaparecido na Guerrilha do Araguaia, em outubro de 1973 (Almeida et al., 2009, p. 472-75), e membro da Comissão de Familiares:

A ideia de fazer o memorial surgiu entre os familiares que compunham a Comissão da Verdade de São Paulo. Queríamos inaugurar o memorial para homenagear todos os mortos e desaparecidos políticos enterrados ali, sobretudo para que o ímpeto memorialístico inaugurado pela Comissão Nacional da Verdade não se acabasse. Sentimos necessidade de lembrar todos os enterrados no maior cemitério da América Latina, e não apenas Virgílio Gomes da Silva e Sérgio Corrêa, homenageados pela Prefeitura de São Paulo através da construção do jardim, localizado na chamada 'quadra dos terroristas'. Depois de enfrentar diversos problemas burocráticos e a falta de apoio

\footnotetext{
${ }^{46}$ Para estabelecer a investigação sobre a edificação do monumento, foram coletados o testemunho de Adriano Diogo e dos familiares dos desaparecidos políticos, cujas histórias se destacaram durante a Audiência Pública sobre os Cemitérios de Perus e de Vila Formosa, promovida pela CEV "Rubens Paiva", em 20/05/2013. Cf. CEV/ SP, "Métodos e Técnicas de Ocultação de corpos na Cidade de São Paulo", op. cit., p. 10

${ }^{47}$ Disponivel em: <https://www.jusbrasil.com.br/diarios/133474140/dom-sp-suplemento-15-12-2016-pg-63>. Acesso em 10/01/2017.

48 SMS, 2016, p. 13.
} 
material, decidiu-se contatar o arquiteto Marcos Cartum, que é amigo do Adriano Diogo, e pedir-lhe auxílio para idealizar esse projeto antes do término do mandato do prefeito Haddad. Daí que a inauguração foi rápida e discreta. ${ }^{49}$

Em julho de 2016, familiares, funcionários do Serviço Funerário e do cemitério, além de Adriano Diogo e do arquiteto Marcos Cartum, reuniram-se para debater o projeto do local de recordação, com o objetivo de homenagear e celebrar a atuação política dos militantes assassinados e enterrados na vala comum de Vila Formosa. No final desse ano, o memorial foi construído com adaptações, a partir do projeto de Cartum. A obra é composta por uma lâmina de concreto de $1,60 \mathrm{~m}$ de altura. Em frente a ela, sobre uma laje de concreto, estão alinhados dez toras ou dez assentos, representando os dez desaparecidos homenageados no memorial (Figuras 2 e 3).

Figuras 2 e 3: O Memorial, pouco antes do descerramento da placa dedicada aos Desaparecidos Políticos da vala comum de Vila Formosa, dezembro de 2016

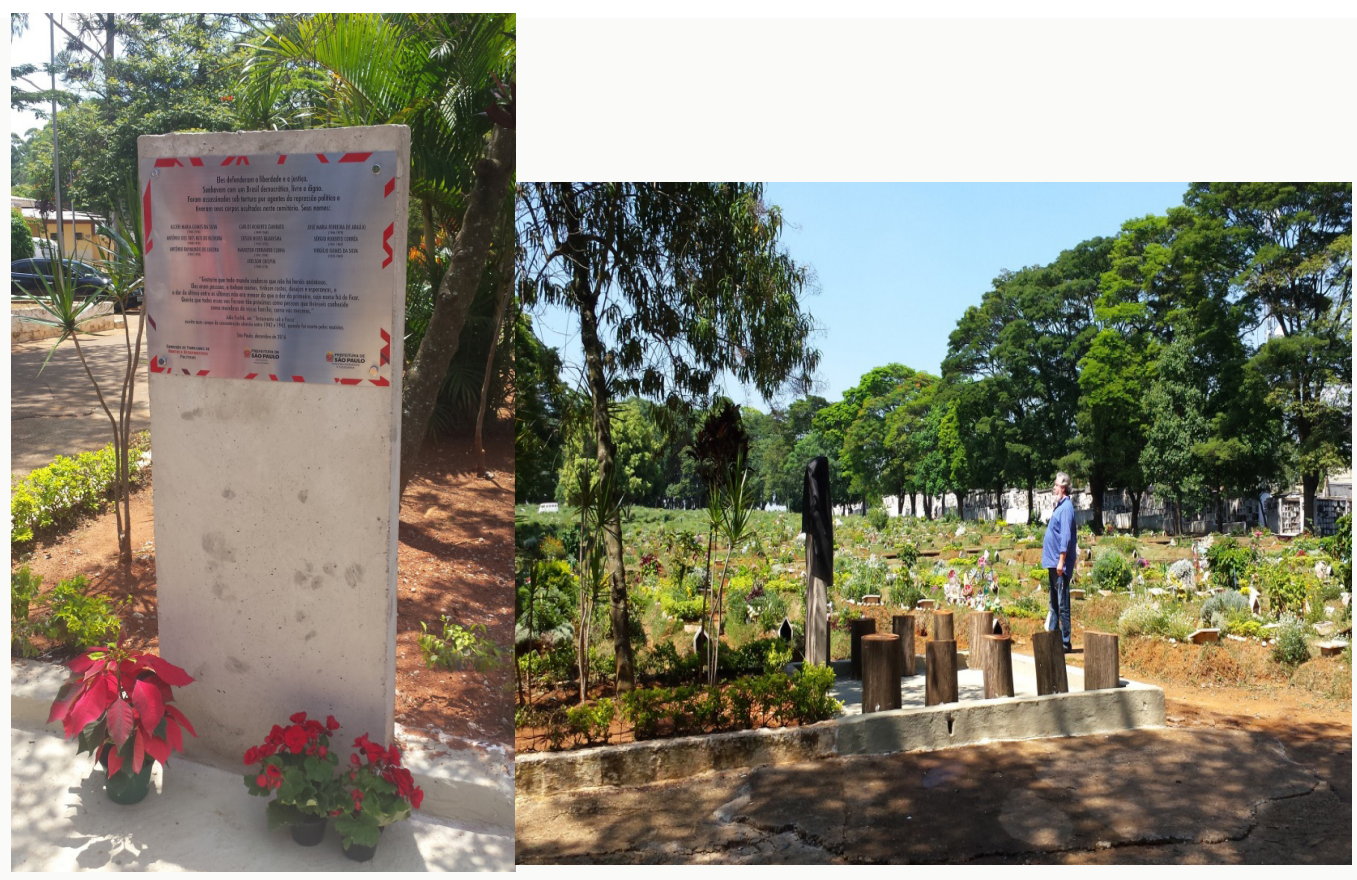

Fonte: Fotografias da autora. Dezembro de 2016

O arquiteto atuou como voluntário, pois não foi possível organizar um concurso público para sua construção. Cartum faz menção ao contexto e às ideias que nortearam a concepção desse espaço de recordação:

Fizemos uma visita ao cemitério e [...] Pareceu-me importante implantar uma obra que expressasse a violência praticada naquele local, expondo e denunciando a história que se passou ali. Era necessário transformar um espaço que era uma espécie de monumento ao esquecimento e

${ }^{49}$ Criméia Alice S. de Almeida. Entrevista concedida a Janaína de A. Teles. São Paulo/SP, 09/01/2017. 
à violência em um monumento à memória e à valorização da consciência e da luta. Na concepção inicial haveria uma grande rocha, uma pedra bruta, na qual seria fixada uma placa com os dizeres dos familiares. Houve dificuldades para obter apoio material e isso impossibilitou a obtenção da rocha, que teve de ser substituída por uma lâmina de concreto, muito singela. Eu gosto da ideia de não precisar traduzir o significado do memorial, mas para mim a rocha significaria a força do indestrutivel, que é a memória. Seria uma referência ao que essas pessoas representam para a continuidade de uma luta. A rocha exprime isso. E, também, na sua brutalidade e no seu estado de natureza, representa a exposição de uma verdade, na sua nudez! No final, a perda da rocha como elemento dramático e a simplificação do projeto me agradou, porque o memorial ganhou em singeleza e sua força está nessa radical simplicidade. Ao invés do monumento destacar-se por meio de uma forma autoral, como é usual, sua expressividade simbólica apoia-se no arranjo delicado de elementos comuns capazes de chamar a atenção para o lugar, para o tema e para a história. Isso é mais eficiente do ponto de vista do estímulo da consciência e à formação educativa [Figuras 2 e 3]. Outro aspecto rico em significado é que o monumento explicita que foi construído de forma intensamente participativa, a partir do trabalho dos funcionários do cemitério. $^{50}$

Em 28 de dezembro de 2016 foi inaugurado o Memorial dos Desaparecidos de Vila Formosa, no espaço da antiga vala comum, graças às doações e cotização dos funcionários do SFM/SP. ${ }^{51} \mathrm{~A}$ inscrição registrada na placa do memorial, assinada pela Comissão de Familiares, faz referência aos crimes praticados pela ditadura, assim como ao projeto político ao qual os militantes se dedicaram, ainda que de maneira sucinta, tal como se pode ler:

Eles defenderam a liberdade e a justiça. Sonhavam com um Brasil democrático, livre e digno. Foram assassinados sob tortura por agentes da repressão política e tiveram seus corpos ocultados nesse cemitério. Seus nomes são... [seguem os nomes com as devidas datas de nascimento e desaparecimento].

A inscrição remete ao debate em torno das reconstruções históricas efetuadas desde a transição democrática no Brasil, que resultaram em uma série de deslocamentos de sentido do passado recente na memória social, que teriam atenuado o caráter revolucionário dos projetos das esquerdas daquele período, segundo Daniel Aarão Reis Filho. De acordo com o historiador, as esquerdas não eram democráticas. Nestes termos, o primeiro deslocamento de sentido do passado implicou na apresentação das esquerdas como parte da "resistência democrática". Esta prática, aplicada na estratégia de mobilização de setores variados da sociedade em torno da campanha pela anistia, teve ampla repercussão, mas teria minimizado o caráter ofensivo e socialista dos projetos das esquerdas (Reis Filho, 2000).

50 Marcos Cartum. Entrevista concedida a Janaína de A. Teles. São Paulo/SP, 08/01/2017.

${ }^{51}$ Criméia Alice S. de Almeida. Entrevista concedida a Janaína de A. Teles. São Paulo/SP, 09/01/2017. 
De acordo com a ex-guerrilheira do Araguaia, Criméia de Almeida, a ausência de menção explícita ao projeto revolucionário dos desaparecidos está associada à estratégia discursiva utilizada na campanha da anistia e à necessidade de envolver todos familiares no movimento:

Na época, estávamos preocupados em dialogar com a população, de não criar zonas de conflito com grupos políticos como o Partido Comunista Brasileiro (PCB) e queríamos abarcar todos os familiares, inclusive, aqueles que não tinham militância partidária, como muitas mães e pais de desaparecidos. Então, falávamos das propostas dos que morreram de maneira mais genérica e essa prática permaneceu, em respeito a todas as visões políticas e como um meio de ampliar nossa luta. Essas pessoas fizeram parte da resistência à ditadura e nós sempre mencionamos os nomes dos partidos aos quais pertenceram, resgatamos a história de vida e da militância deles, tanto nos panfletos e livros, quanto nas pesquisas que fizemos nos arquivos do DOPS, entre outras. ${ }^{52}$

É de se ter em vista que, no período pós-1964, as lutas de resistência à ditadura e as de transformação social influenciaram-se mutuamente, assim como as diversas propostas e matrizes ideológicas de construção e exercício da democracia. Modelos variados de democracia representavam uma referência política para distintos grupos, o que coloca em perspectiva a crítica dirigida às esquerdas da época, de que estas não eram democráticas (Ridenti, 1993; Teles, 2011).

Consta ainda na placa do memorial uma citação de Júlio Fuchik, dirigente do Partido Comunista da antiga Tchecoslováquia, preso em Praga pela Gestapo, em 24 de abril de 1942, e condenado à morte por alta traição nos tribunais nazistas. Ele foi enforcado em Berlin, em 08 de setembro de 1943:

Só vos peço uma coisa: se sobreviverdes a esta época, não vos esqueçais nem dos bons, nem dos maus. Juntais com paciência as testemunhas daqueles que tombaram por eles e por vós. Um belo dia, hoje será passado, e falarão numa grande época e nos heróis anônimos. Eles eram pessoas e tinham nomes, rostos, desejos e esperanças, e a dor do último não era menor do que a dor do primeiro, cujo nome há de ficar. Queria que todos esses vos fossem tão próximos como as pessoas que tivésseis conhecido como membros de vossa família, como vós mesmos. ${ }^{53}$

\footnotetext{
${ }^{52}$ Criméia Alice S. de Almeida. Entrevista concedida a Janaína de A. Teles. São Paulo/SP, 09/01/2017.

53 Membro do Comitê Central do PCT, Fuchik foi preso em Praga pela Gestapo. Inicialmente, ficou detido na prisão local de Pankrác. Ali redigiu as anotações que compõem o livro Testamento sob a forca, levados para fora da prisão por guardas que simpatizavam com ele. Em maio de 1943, foi levado preso para Bautzen, na Alemanha, e, depois, para Berlim. Em 25/08/43, foi acusado de alta traição e condenado à morte, tendo sido enforcado logo depois, cf. Fuchik (2013).
} 
No projeto do memorial, o arquiteto Marcos Cartum procura estabelecer uma relação com os desaparecidos homenageados, aproximando-nos das experiências e lembranças do passado, tal como sugerem as palavras de Fuchik. Ele próprio, o arquiteto, possui uma relação especial com esse passado, pois, com dez anos, em 1970, passou a visitar o tio, no presídio Tiradentes. Rubens Hirsel Bergel, irmão de sua mãe e militante da VPR, permaneceu no cárcere por dois anos. Bergel havia organizado um centro médico clandestino da VPR, criado para socorrer guerrilheiros eventualmente feridos. ${ }^{54}$ Foi no Tiradentes em que Cartum tomou contato pela primeira vez com a perseguição política e a violência da ditadura:

Sou mais novo, quando fiz 18 anos a ditadura já estava em declínio, era o início das greves metalúrgicas. Eu já havia tido contato com a questão da repressão, pois meu tio foi preso político e eu o visitava no presídio Tiradentes... Tive uma politização precoce. Além disso, sou judeu. Meus avós vieram da Lituânia e meu pai da Letônia [...]. A cultura dos imigrantes e dos judeus, em particular, é toda ligada à perseguição, à transitoriedade e à fragilidade dessas situações. Essa origem certamente me aproximou dessa temática, porque para os judeus a memória substitui o lugar, como se a história desempenhasse a função de território. A história é seu lugar de enraizamento. Sinto-me herdeiro de uma nostalgia, mas de algo não muito bom... No caso do meu pai, sua nostalgia estava relacionada ao fato de não ter conseguido emigrar para construir o Estado de Israel. Creio que isso contribuiu para me aproximar do tema da memória e da luta contra a violação dos direitos humanos. Assim, tenho participado de vários projetos ligados à requalificação de espaços de maneira a tornar viva a memória do que se passou na ditadura. Um exemplo disso é o Memorial da Luta pela Justiça, a ser implantado pela OAB/SP e o Núcleo de Memória, em São Paulo. ${ }^{55}$

A atmosfera de medo gerada pelo terror de Estado disseminado no período não passou despercebida para Cartum. Essa experiência se refletiu na maneira como o arquiteto criou o memorial, considerado desde o registro da violência estatal, como um espaço que combina memória e esquecimento, trabalho de recordação e recalque. Nesse sentido, a vala clandestina de Vila Formosa pode ser considerada como uma ferida (trauma, em grego). Um rastro da violência que persiste, advertindo-nos para não esquecer e para que nunca mais aconteça. Sua conservação é condição para torná-lo portador de novas significações, e sumário de outras narrativas do passado (Assman, 2011, p. 352).

$\mathrm{Na}$ medida em que o memorial se voltou aos considerados "indesejáveis", segundo os ideólogos da ditadura, ele projeta outra visão da história na cena da rememoração pública, favorecendo uma reflexão crítica do passado recente. A memória do trauma, assim como a própria recuperação dessa história, revela sua precariedade, mas também sua capacidade de resistência, tornando-se um relevante recurso que, eventualmente, interpõe-se ao sofrimento e à injustiça, como sugere o testemunho de Gregório Gomes da Silva, filho de Virgílio G. da Silva,

54 Brasil: Nunca Mais. Processo no.162/70, Justiça Militar, disponível em: < http://bnmdigital.mpf.mp.br/DocReader/ DocReader.aspx?bib=BIB_01\&PagFis=73557>.

55 Marcos Cartum. Entrevista concedida a Janaína de A. Teles. São Paulo/SP, em 08/01/2017. 
que cresceu no exílio, em Cuba, nos anos 1970:

\begin{abstract}
Para mim, apenas em 2004, com as descobertas dos documentos sobre meu pai, reascendeu a esperança de que encontraríamos os restos mortais dele. Algumas vezes, tentamos encontrá-los e não conseguimos! $E$ aí descobrimos que a quadra foi toda alterada... A gente sempre quis achar, porque é difícil conviver com o desaparecimento de um pai, isso era um compromisso que tínhamos com minha avó, que ficou no Brasil procurando por ele até morrer... Eu queria ter um lugar para fazer as homenagens a ele e para pensar na vida. Sempre assumi como referência o exemplo de vida do meu pai e sempre quis ter um lugar para essa conversa comigo mesmo. Para avaliar se estou seguindo o caminho que eu e ele traçamos juntos, no plano espiritual... nas minhas conversas [imaginadas] com ele... Acreditei que poderia ter um lugar para fazer esse tipo de reflexão! Neste sentido, o jardim, inaugurado em Vila Formosa, foi fantástico. Pra mim, não ter achado o corpo do meu pai, foi até melhor. Pois, assim ele pode estar em qualquer lugar, não apenas naquela quadra do jardim ou na vala clandestina... em São Paulo ou no Brasil. E, dessa maneira, o cemitério fica reservado como um lugar de encontro, de conversa, de reflexão. Agora temos dois lugares para isso lá. ${ }^{56}$
\end{abstract}

A vala clandestina de Vila Formosa está vinculada à violência contra os dissidentes da ditadura. Trata-se de um local demarcado pelos sobreviventes, mas também da manifestação de uma memória involuntária, que "traz à luz uma descoberta tardia repentina" (Assman, 2011, p. 358), do descaso do poder público com os dissidentes e com a população pobre, vinculada aos restos mortais de 90 pessoas esquecidas na vala, vítimas do período democrático. Para familiares e sobreviventes, a vala preserva a violência "de um acontecimento que permanece, como um passado que não se esvai, que não logra guardar distância" (Assman, 2011, p. 350). A vala é como uma ferida que não pode cicatrizar, simbolizando um luto inacabado, de um passado "que não passa".

Tal como em Perus, a vala de Vila Formosa e o próprio memorial constituem a asseguração arqueológica dos vestígios de um passado traumático, que se quis soterrar. Ela é um local que estabelece uma ligação com esse passado, um vínculo entre presença e ausência, que insiste em apartar o aqui do outrora. Por um lado, busca estabelecer um trabalho de luto, tardio. É um espaço que, combinado com a recuperação de sua história, suscita estranheza e conduz à percepção "do afastamento e a distância irrecuperável do passado" (Assman, 2011, p. 357 e 360).

Para além da presença da palavra escrita na pedra, à semelhança das antigas práticas funerárias e de comemoração, é patente o valor atribuído à visão e à imaginação, no ato de rememorar proposto pelo memorial. Com aspecto simples e direto, o memorial de Vila Formosa objetiva explicitar um passado, que muitos resistem em dirigir o olhar. Desse modo, familiares e militantes apostam na força das palavras, dos gestos e dos rituais efêmeros, em um esforço de recordar e imaginar o passado de maneira (cri)ativa.

56 Gregório Gomes da Silva. Entrevista concedida a Janaína de A. Teles. São Paulo/SP, 06/01/2017. 
Os familiares de mortos e desaparecidos políticos, particularmente, investiram na capacidade de criar rituais e atualizar símbolos da resistência à ditadura. Durante os anos 1990, o memorial de Perus, por exemplo, foi o palco no qual d. Paulo Evaristo Arns celebrou missas, no dia de finados, em homenagem às lutas de resistência e àqueles não estão mais presentes, reeditando as missas celebradas na Praça da Sé, ${ }^{57}$ nos anos 1970. A cada ano, por outro lado, renova-se a pauta a ser abordada no ato público que relembra Carlos Marighella, ${ }^{58}$ em seu memorial em São Paulo, entre outros.

O Memorial de Vila Formosa é mais um a compor o processo de (re)construção da identidade dos sobreviventes e de familiares, integrando a paisagem histórica da cidade. As atividades direcionadas a recomeçar e recordar permeiam o percurso das lutas políticas e das significações culturais, mas a "persistência dos locais" pode contribuir ao estabelecimento de uma "memória de longa duração" (Assman, 2011, p. 358-59) sobre a repressão ditatorial.

Depositar flores e discursar diante do Memorial de Vila Formosa pode se transformar em um hábito de familiares e populares, de modo a tornar-se um símbolo que transcende a função de suporte terapêutico para os sobreviventes. Estes têm reiventado, a cada época, novas maneiras de tornar visíveis esses personagens históricos, e a temática do "direito à memória e à verdade" no Brasil. Desse modo, este memorial tem a capacidade de se transformar em mais um exemplo profícuo das relações entre história e memória, que podem criar tensões em uma dialética aberta, em face da qual esta se preserva das pretensões daquela de reduzir-lhe a um de seus objetos e, opostamente, do afã da "memória coletiva de avassalar a história com as comemorações impostas pelo poder político ou pelos grupos de pressão" (Ricoeur, 2007, p. 403).

\section{Considerações finais}

A despeito dos limites impostos pela transição controlada, as memórias, experiências e o local de recordação aqui analisados favorecem a constituição de uma consciência coletiva acerca da repressão ditatorial e do status de suas vítimas e sobreviventes. Não obstante, mesmo após a conclusão dos trabalhos da Comissão Nacional da Verdade, ${ }^{59}$ o Brasil mantém-se como modelo de impunidade e atraso na promoção da reconstituição factual dos crimes da ditadura

\footnotetext{
${ }^{57}$ A resistência ao arbítrio fez-se presente nas missas celebradas na Catedral da Sé em homenagem aos mortos e desaparecidos políticos, ao longo dos anos 1970. A primeira de que se tem notícia foi a missa celebrada em homenagem a Luis E. da R. Merlino, em agosto de 1971. A missa em memória de Alexandre Vannuchi Leme, estudante da USP assassinado sob tortura, celebrada por D. Paulo E. Arns em março de 1973, teve grande repercussão, contando com a presença de 3.000 pessoas. Seguiram-se outras que foram decisivas para impor desgaste político à ditadura, tais como a missa ecumênica em memória de Herzog, em 1975, a de Manoel Fiel Filho e a de Santo Dias da Silva, entre outras (Teles, 2017, p. 187-198 e 277-87).

58 Marighella ingressou no PCB nos anos 1930. Foi detido diversas vezes, tendo permanecido 6 anos preso, durante a ditadura Vargas. Elegeu-se deputado federal constituinte pelo PCB baiano, em 1946. Neste mesmo ano, perdeu o mandato, devido à proscrição do PCB. Voltou a atuar na clandestinidade e ocupou diversos cargos na direção partidária. Passou os anos de 1953 e 1954 na China, a fim de conhecer a revolução chinesa. Logo após o golpe, foi baleado e preso em maio de 1964. Em 1966, renunciou ao cargo na Comissão Executiva Nacional do PCB e, em 1967, participou da I Conferência da OLAS (Organização Latino-Americana de Solidariedade), realizada em Havana, Cuba. Logo depois, foi expulso do partido e fundou a ALN. Em novembro de 1969, Marighella é vítima de uma emboscada e assassinado em São Paulo (Almeida, 2009, p. 160-63.

${ }^{59}$ Comissão Nacional da Verdade (doravante CNV). Relatório da Comissão Nacional da Verdade, 2014.
} 
e da justiça, conforme demonstra o recente relatório do Ministério Público Federal. ${ }^{60}$

A despeito dos avanços mencionados, os mecanismos de denegação e bloqueio de uma ampla difusão de testemunhos sobre a ditadura, e de processos de responsabilização pelos crimes cometidos pelo Estado neste período permanecem dificultando a realização de uma efetiva investigação, assim como de um debate abrangente sobre seu legado na sociedade. Com efeito, o Brasil avançou a partir de algumas experiências, mas não conseguiu aproveitar a oportunidade, para dar a máxima visibilidade aos testemunhos referentes à ditadura na esfera pública. Aqueles fatos, pertinentes a toda a sociedade, deveriam inscrever-se na memória pública, por meio da experiência transmitida pelo testemunho, incorporando-se à história do país. Mais uma vez, o Brasil perdeu uma oportunidade de gerar processos de justiça e responsabilização, que efetivamente refletissem a magnitude da violência estatal do período. Nesse sentido, não foi possível o estabelecimento de rupturas com as práticas e instituições remanescentes da ditadura.

Essa realidade contribui sensivelmente para a irresolução dos conflitos relativos ao período ditatorial. Trata-se de uma "lógica astuta" do Estado brasileiro (Safatle, 2005, p. 34), pois ao mesmo tempo em que reconhece as demandas das vítimas e sobreviventes por reparações e políticas públicas de memória, desloca para a periferia do universo político a apuração dos crimes cometidos pelo Estado durante a ditadura, o debate sobre os sentidos dessa experiência, bem como sobre a responsabilização por tais crimes.

Nesse sentido, é de se ressaltar o quanto a experiência brasileira de (re)democratização contrasta com a de diversos países latino-americanos. Os pedidos de retorno dos militares e evidentes retrocessos políticos e sociais recentes indicam que a estratégia de não priorizar a defesa dos direitos humanos, em detrimento de "acordos" pretéritos fracassou. Mas, sobretudo, que a (re)construção da democracia brasileira necessariamente, deve incorrer no enfrentamento desse passivo, legado pela ditadura.

\section{Referências Bibliográficas}

ADES, César. Múltipla Memória. Memória: Revista Psicologia da USP. São Paulo, v. 4, n. 1-2, p. 9-24, 1993.

ADORNO, Theodor. Educação e Emancipação. São Paulo: Paz e Terra, 1995. 190p.

ALMEIDA, Criméia de Schmidt; LISBÔA, Suzana Keniger; TELES, Janaína de Almeida e TELES, Maria Amélia de Almeida (Orgs.). Dossiê Ditadura: mortos e desaparecidos políticos no Brasil (1964-1985). São Paulo: IEVE/Imprensa Oficial, 2009. 776p.

ARAÚJO, Ñasaindy Barrett de. Duas pátrias, duas mães. In: Assembléia legislativa; Comissão da

\footnotetext{
${ }^{60}$ Ministério Público Federal e Câmara de Coordenação e Revisão, Criminal, 2a. Crimes da ditadura militar. 2ª Câmara de Coordenação e Revisão, Criminal. - Brasília: MPF, 2017. 348p. Disponível em: <http://www.mpf.mp.br/atuacaotematica/ccr2/publicacoes/roteiro-atuacoes/005_17_crimes_da_ditadura_militar_digital_paginas_unicas.pdf>. Acesso em: 25/04/2017
} 
Verdade do Estado de São Paulo. Infância Roubada. Crianças atingidas pela ditadura militar no Brasil. São Paulo: ALESP, p. 100-103, 2014.

ARQUIDIOCESE de São Paulo. 22a. ed. Brasil: Nunca Mais - um relato para a história. Petrópolis/ RJ: Vozes, 1989. 312p.

Perfil dos Atingidos. Projeto "Brasil: Nunca Mais". Tomo III, Petrópolis/RJ: Ed. Vozes, 1988. 312p.

ASSMANN, Aleida. Espaços de recordação. Formas e transformações da memória cultural. Campinas/SP: Edunicamp, 2011. 456p.

CALIGIURI FILHO, Júlio César et al. Onde estão? Relatório da Comissão Parlamentar de Inquérito que investigou a vala clandestina no Cemitério Dom Bosco, em Perus, e os desaparecidos políticos. São Paulo: Câmara Municipal de São Paulo, 1992. 47p.

CAPELATO, Maria Helena R. Memórias da ditadura militar argentina: um desafio para a história. São Paulo, 2007, mimeo. 23p.

CATELA, Ludmila da Silva. Situação-limite e Memória. A Reconstrução do Mundo dos Familiares. São Paulo: Hucitec, 2001. 399p.

FREUD, Sigmund. Notas sobre um caso de neurose obsessiva (O homem dos ratos). Rio de Janeiro: Imago, 1998. 142p. Luto e melancolia. In: Artigos sobre Metapsicologia. Rio de Janeiro: Imago, 1999. 186p.

FUCHIK, Júlio. Testamento sob a forca. 2ª. ed., Rio de Janeiro, Revan, 2013. 128p.

HUYSSEN, Andreas. En busca del futuro perdido. Cultura y memoria en tiempos de globalización. México: FCE, 2002. 284p.

JELIN, Elizabeth. Los trabajos de la memoria. Madrid: Siglo XXI, 2002. 156p.

KEHL, Maria Rita. O ressentimento. São Paulo: Casa do Psicólogo, 2005. 253p.

LE GOFF, Jacques. História e Memória. 3a. ed. Campinas (SP): Ed. Unicamp, 1994. 504p.

LEITÃO, Matheus. Edinho, procurado vivo ou morto. Época. Rio de Janeiro, no 582, 11/07/2009. Disponível em: <http://revistaepoca.globo.com/Revista/Epoca/0,EMI81888-15223,00EDINHO+PROCURADO+VIVO+OU+MORTO.html>. Acesso em: 08/10/2011.

MONTENEGRO, Antonio Torres; RODEGHERO, Carla Simone; e ARAÚJO, Maria Paula (orgs.). Marcas da Memória: história oral da anistia no Brasil. Recife: Ed. Universitária da UFPE, 2012. 212p.

NASIO, Juan-David. Lições sobre os 7 conceitos cruciais da psicanálise. Rio de Janeiro: Zahar, 1997. 204p. 
OBERTI, Alejandra. El valor del testimonio: usos, accesos y saberes. Seminário Internacional 30 Anos de Anistia no Brasil: o direito à memória, à verdade e à justiça. São Paulo: FADUSP, 25-28 de setembro de 2009.

QUINALHA, Renan. Nem justiça, nem reconciliação: reflexões sobre a Comissão Nacional da Verdade no Brasil. São Paulo, Painel Acadêmico, 12/11/2015. Disponível em: <http://painelacademico.uol. com.br/painel-academico/5517-nem-justica-nem-reconciliacao-reflexoes-sobre-a-comissaonacional-da-verdade-no-brasil?. Acesso em: 10/02/2017.

REIS FILHO, Daniel Aarão. Ditadura militar, esquerdas e sociedade. Rio de Janeiro: Zahar, 2000. 88p.

RICOEUR, Paul. A memória, a história, o esquecimento. Campinas: Unicamp, 2007. 536p.

RIDENTI, Marcelo. O fantasma da revolução brasileira. São Paulo: Edunesp, 1993. 284p.

ROUSSO, Henry. La trayectoria de un historiador del tiempo presente, 1975-2000. In: PÉROTINDUMON, Anne. (Dir.). Historizar el pasado vivo en América Latina, 2007, p. 07-110. Disponível em: <http://www.historizarelpasadovivo.cl/downloads/rousso.pdf>. Acesso em 15/12/2016.

SAFATLE, Vladimir. "Encontro marcado". Reportagem. Belo Horizonte, n. 65, p. 31-34, fev., 2005. Disponível em: <http://www.oretratodobrasil.com.br/reportagem/65/pdf/9.pdf>. Acesso em: 10/02/2017.

SARLO, Beatriz. Tempo Passado. Cultura da memória e guinada subjetiva. São Paulo: Companhia das Letras/UFMG, 2007. 136p.

SELIGMANN-SILVA, Márcio. A história como trauma. In: e NESTROVSKI, Arthur (orgs.). Catástrofe e Representação. São Paulo, Escuta, p. 73-98, 2000.

Apresentação da questão. In: (Org.). História, Memória, Literatura. O testemunho na era das catástrofes. Campinas: Ed. Unicamp, p. 45-58, 2003.

Antimonumentos: a memória possivel após as catástrofes. In: FERREIRA, Maria Letícia Mazzucchi \& MICHELON, Francisca Ferreira (Orgs.). Memória e Esquecimento. Pelotas: Ed. UFPel, p.141-173, 2012.

TELES, Janaína de Almeida. Os herdeiros da memória: a luta dos familiares de mortos e desaparecidos políticos por "verdade e justiça" no Brasil. Dissertação (Mestrado em História). Programa de PósGraduação em História, USP, 2005, 268p.

Memórias dos cárceres da ditadura: as lutas e os testemunhos dos presos políticos no Brasil. Tese (Doutorado em História). Programa de Pós-Graduação em História, USP, São Paulo, 2011, 518p.

A constituição das memórias sobre a repressão da ditadura: o projeto Brasil: Nunca Mais e a abertura da Vala de Perus. Revista Anos 90. Porto Alegre, v. 19, n. 35, p. 261-298, 2012.

Os herdeiros da memória: as lutas dos familiares de mortos e desaparecidos politicos no 
Brasil. São Paulo, Alameda, 2017 (no prelo).

TELES, Edson. Democracia e Estado de Exceção. Transição e Memória Política no Brasil e África do Sul. São Paulo: Fap-Unifesp, 2015, 220p.

TRAVERSO, Enzo. El pasado, instrucciones de uso. Historia, memoria, política. Madrid, Marcial Pons. 2007. 117p.

VALLI, Virgínia. Eu, Zuzu Angel, procuro meu filho. A verdadeira história de um assassinato político. Rio de Janeiro, Record, 1987, 237p.

WEICHERT, Marlon Alberto e FÁVERO, Eugênia A. Gonzaga. "Relatório sobre os trabalhos de localização e identificação de despojos de desaparecidos políticos nos cemitérios de Perus e Vila Formosa". São Paulo: MPF/SP, 10/09/2010, 17p.

WEICHERT, Marlon Alberto. O relatório da Comissão Nacional da Verdade: Conquistas e desafios. Projeto História. São Paulo, n. 50, p.86-137, Ago/2014.

WEINRICH, Harald. Lete. Arte e crítica do esquecimento. Rio de Janeiro: Civilização Brasileira, 2001. 346p.

WESCHLER, Lawrence. Um milagre, um universo: o acerto de contas com os torturadores. São Paulo: Companhia das Letras, 1990. 296p.

WINTER, Jay. A geração da memória: as reflexões sobre 'boom da memória' nos estudos contemporâneos de história. In: SELIGMANN-SILVA, Márcio. (org.). Palavra e imagem: memória e escritura. Chapecó: Argos, p. 67-90, 2006.

Recebido em: 12 de fevereiro de 2017

Aprovado em: 27 de abril de 2017 